\title{
The Role of Temperature in Transmission of Zoonotic Arboviruses
}

\author{
Alexander T. Ciota ${ }^{1,2, *}$ and Alexander C. Keyel ${ }^{1,3}$ (D) \\ 1 Wadsworth Center, New York State Department of Health, Albany, NY 12201, USA; akeyel@albany.edu \\ 2 Department of Biomedical Sciences, State University of New York at Albany School of Public Health, \\ Rensselaer, NY 12144, USA \\ 3 Department of Atmospheric and Environmental Sciences, University at Albany, Albany, NY 12222, USA \\ * Correspondence: alexander.ciota@health.ny.gov; Tel.: +1-518-485-6616
}

Received: 10 October 2019; Accepted: 30 October 2019; Published: 1 November 2019

check for updates

\begin{abstract}
We reviewed the literature on the role of temperature in transmission of zoonotic arboviruses. Vector competence is affected by both direct and indirect effects of temperature, and generally increases with increasing temperature, but results may vary by vector species, population, and viral strain. Temperature additionally has a significant influence on life history traits of vectors at both immature and adult life stages, and for important behaviors such as blood-feeding and mating. Similar to vector competence, temperature effects on life history traits can vary by species and population. Vector, host, and viral distributions are all affected by temperature, and are generally expected to change with increased temperatures predicted under climate change. Arboviruses are generally expected to shift poleward and to higher elevations under climate change, yet significant variability on fine geographic scales is likely. Temperature effects are generally unimodal, with increases in abundance up to an optimum, and then decreases at high temperatures. Improved vector distribution information could facilitate future distribution modeling. A wide variety of approaches have been used to model viral distributions, although most research has focused on the West Nile virus. Direct temperature effects are frequently observed, as are indirect effects, such as through droughts, where temperature interacts with rainfall. Thermal biology approaches hold much promise for syntheses across viruses, vectors, and hosts, yet future studies must consider the specificity of interactions and the dynamic nature of evolving biological systems.
\end{abstract}

Keywords: arbovirus; temperature; vector competence; vectorial capacity; flavivirus; alphavirus; orthobunyavirus; phlebovirus; Culex; Aedes

\section{Introduction}

Global temperatures have increased by an average of $0.85{ }^{\circ} \mathrm{C}(0.65-1.06)$ from $1880-2012$ [1]. The International Panel on Climate Change predicts a further acceleration of global temperature rise, with an additional $1.4-3.1^{\circ} \mathrm{C}\left(\mathrm{RCP}\right.$ 6.0) or $2.6-4.8^{\circ} \mathrm{C}(\mathrm{RCP} 8.5)$ by the end of the century if there is no change to greenhouse gas emissions [1]. Temperature has been shown to have a significant influence on the transmission of many infectious agents, including arthropod-borne viruses (arboviruses) [2,3]. This results from a range of effects of temperature on biological processes influencing host, vector and virus. The complexity of enzootic transmission cycles makes understanding the role of temperature a challenge. Here, we review the role of temperature in major zoonotic arboviruses (Table 1). Viruses were limited to those that (1) are associated with human disease, (2) have a primarily non-human amplifying host, (3) are primarily vectored by mosquitoes, and (4) have at least one study examining temperature effects. We summarize studies examining temperature effects on Vector Competence, Life History Traits, Blood-feeding Behavior, Vector and Host Distribution, and Viral Distribution; and 
subsequently address gaps in the field that should be the focus of future studies. Since the epidemiology and ecology of each virus has been adequately reviewed elsewhere (Table 1) we focus exclusively on the influence of temperature on transmission dynamics.

Table 1. Zoonotic mosquito-borne viruses commonly associated with human disease.

\begin{tabular}{|c|c|c|c|c|}
\hline Species & Primary Vector & Primary Hosts & Distribution $^{1}$ & Human Disease \\
\hline \multicolumn{5}{|c|}{ Togaviridae: alphaviruses } \\
\hline $\begin{array}{c}\text { Eastern equine encephalitis } \\
\text { virus (EEEV) [4] }\end{array}$ & $\begin{array}{l}\text { mosquito (Culiseta, } \\
\text { Culex) }\end{array}$ & bird & NA, C/SA & $\begin{array}{l}\text { febrile illness, } \\
\text { encephalitis }\end{array}$ \\
\hline $\begin{array}{l}\text { Western equine encephalitis } \\
\text { virus (WEEV) [5] }\end{array}$ & $\begin{array}{l}\text { mosquito (Culiseta, } \\
\text { Culex) }\end{array}$ & bird & NA, C/SA & $\begin{array}{l}\text { febrile illness, } \\
\text { encephalitis }\end{array}$ \\
\hline Sindbis virus (SINV) [6] & mosquito (Culex) & bird & $\begin{array}{c}\mathrm{AF}, \mathrm{EU}, \mathrm{AS}, \mathrm{ME}, \\
\mathrm{AU}\end{array}$ & $\begin{array}{l}\text { febrile illness, } \\
\text { arthralgia }\end{array}$ \\
\hline Ross River virus (RRV) [7-10] & $\begin{array}{l}\text { mosquito (Aedes, } \\
\text { Culex) }\end{array}$ & $\begin{array}{c}\text { mammals } \\
\text { (marsupials) }\end{array}$ & $\mathrm{AU}$ & $\begin{array}{l}\text { febrile illness, } \\
\text { arthralgia }\end{array}$ \\
\hline Barmah forest virus (BFV) [7] & mosquito (Aedes) & $\begin{array}{c}\text { mammals } \\
\text { (marsupials) }\end{array}$ & AU & $\begin{array}{l}\text { febrile illness, } \\
\text { arthralgia }\end{array}$ \\
\hline $\begin{array}{c}\text { Venezuelan equine encephalitis } \\
\text { virus (VEEV) [11] }\end{array}$ & $\begin{array}{l}\text { mosquito (Aedes, } \\
\text { Culex) }\end{array}$ & $\begin{array}{l}\text { small mammal, } \\
\text { equids }\end{array}$ & $\mathrm{NA}, \mathrm{C} / \mathrm{SA}$ & $\begin{array}{l}\text { febrile illness, } \\
\text { encephalitis }\end{array}$ \\
\hline Mayaro virus (MAV) [12] & $\begin{array}{l}\text { mosquito } \\
\text { (Haemagous) }\end{array}$ & $\begin{array}{l}\text { non-human } \\
\text { primate }\end{array}$ & C/SA & $\begin{array}{l}\text { febrile illness, } \\
\text { arthralgia }\end{array}$ \\
\hline \multicolumn{5}{|c|}{ Bunyaviridae: orthobunyaviruses } \\
\hline Lacrosse virus (LACV) [13] & mosquito (Aedes) & small mammal & NA & $\begin{array}{l}\text { febrile illness, } \\
\text { encephalitis }\end{array}$ \\
\hline \multicolumn{5}{|c|}{ Bunyaviridae: phleboviruses } \\
\hline $\begin{array}{c}\text { Rift Valley fever virus (RVFV) } \\
{[14,15]}\end{array}$ & $\begin{array}{c}\text { mosquito } \\
\text { (Aedes/Culex), } \\
\text { phlebotomus flies }\end{array}$ & $\begin{array}{c}\text { mammal } \\
\text { (ruminants) }\end{array}$ & $\mathrm{AF}$ & $\begin{array}{c}\text { febrile illness, } \\
\text { hemorrhagic fever, } \\
\text { encephalitis }\end{array}$ \\
\hline \multicolumn{5}{|c|}{ Flaviviidae: flaviviruses } \\
\hline $\begin{array}{c}\text { Japanese encephalitis virus } \\
\text { (JEV) [15-20] }\end{array}$ & mosquito (Culex) & bird, swine & AS & $\begin{array}{l}\text { febrile illness, } \\
\text { encephalitis }\end{array}$ \\
\hline $\begin{array}{l}\text { Murray valley encephalitis } \\
\text { virus (MVEV) [21] }\end{array}$ & mosquito (Culex) & bird & $\mathrm{AU}$ & $\begin{array}{l}\text { febrile illness, } \\
\text { encephalitis }\end{array}$ \\
\hline $\begin{array}{l}\text { St. Louis encephalitis virus } \\
\text { (SLEV) }[22,23]\end{array}$ & mosquito (Culex) & bird & NA, C/SA & $\begin{array}{l}\text { febrile illness, } \\
\text { encephalitis }\end{array}$ \\
\hline $\begin{array}{c}\text { West Nile virus }(W N V) \\
{[15,24-27]}\end{array}$ & mosquito (Culex) & bird & $\begin{array}{l}\text { NA, C/SA, AF, EU, } \\
\text { ME, AS, AU }\end{array}$ & $\begin{array}{l}\text { febrile illness, } \\
\text { encephalitis }\end{array}$ \\
\hline
\end{tabular}

${ }^{1} \mathrm{NA}=\mathrm{N}$. America, $\mathrm{C} / \mathrm{SA}=\mathrm{C} . / \mathrm{S}$. America, $\mathrm{AF}=$ Africa, $\mathrm{EU}=$ Europe $\mathrm{ME}=$ Middle East $, \mathrm{AS}=\mathrm{Asia}, \mathrm{AU}=$ Australia.

\section{Vector Competence}

Vector competence refers to the inherent capacity of an invertebrate host to become infected and ultimately transmit a given pathogen. For mosquito-borne viruses, this requires infection of the epithelial cells of the mosquito midgut following blood meal acquisition and digestion, efficient replication of the pathogen in the gut, traversing of the basal lamina of the midgut to enter the hemocoel, infection of/replication in the salivary glands, and sufficient accumulation of infectious particles in saliva for transmission to competent hosts [28,29]. Numerous studies have documented highly significant effects of adult holding temperature on vector competence for zoonotic arboviruses of interest (Table 2; [30-49]). Increases in environmental temperature increase viral replication rates in ectothermic hosts, and because viral dissemination is directly correlated to viral load [29,34,50,51], temperature increases should generally result in shorter extrinsic incubation periods (EIPs) and increased overall transmissibility. While this is largely the case, the magnitude of this effect is variable and dependent on the virus species, virus strain, dose, mosquito species, and mosquito population (Table 2; [30,31,37,44]). Kilpatrick et al. [37] demonstrated an accelerated EIP for the WNV02 
genotype strains relative to NY99 genotype strains which was magnified at higher temperatures, yet similar studies by Danforth et al. [31] with distinct mosquito populations and strains measured no strain-specific effect of temperature. Additionally, while replication and subsequently EIP is generally accelerated, the effect on susceptibility is more variable and similarly species-dependent. For instance, studies with Rift Valley fever virus (RVFV) found increased infectivity at increased temperatures for Cx. pipiens [34] but no difference in infectivity at higher temperatures in Ae. fowleri [35]. There is also likely a thermal limit to the correlation between competence and temperature that is virus and mosquito-specific and independent from effects on mosquito fitness (addressed below). For instance, Vogels et al. found increased competence from 18 to $23^{\circ} \mathrm{C}$ in Dutch and Italian populations of $C x$. pipiens, yet further increases from 23 to $28^{\circ} \mathrm{C}$ only increased competence in Italian Cx. pipiens [32]. While there are limited studies that demonstrate decreased competence above a thermal limit with zoonotic arboviruses [33,45,46], this is likely a result of experimental design (most studies have utilized maximum temperatures of between $28-32^{\circ} \mathrm{C}$ ). Although this review does not focus on arboviruses which utilize humans as amplifying hosts, more extensive studies assessing thermal limits and the role of interactions between mosquito genotype, viral genotype and temperature have been completed with dengue, chikungunya and Zika viruses [52-59]. A recent study by Tesla et al. which studied Zika virus competence at a temperature range from $16.0-38.0^{\circ} \mathrm{C}$ found that competence was maximized at $30.6^{\circ} \mathrm{C}$ with significant declines above $34.0^{\circ} \mathrm{C}$, and EIP accelerated up to $36.4^{\circ} \mathrm{C}$, followed by a steep decline [54]. These relationships are likely to be highly variable with different virus strains and mosquito populations. In fact, the influence of mosquito genetics could at times supersede the generic effects of rising temperatures, even at relatively low temperatures, as has been shown by increased transmission of dengue and chikungunya at lower temperatures in some mosquito populations [53,55,56]. Given the specificity of these interactions, future studies with enzootic arbovirus should focus on establishing the relationship of temperature to competence in individual populations with circulating viral genotypes. In addition, a more thorough understanding of the mechanistic basis for population and strain-specific interactions with temperature could significantly increase our capacity to utilize genetic surveillance to predict regional impacts of climate change on arbovirus transmission. 
Table 2. Effect of temperature on vector competence for zoonotic arboviruses.

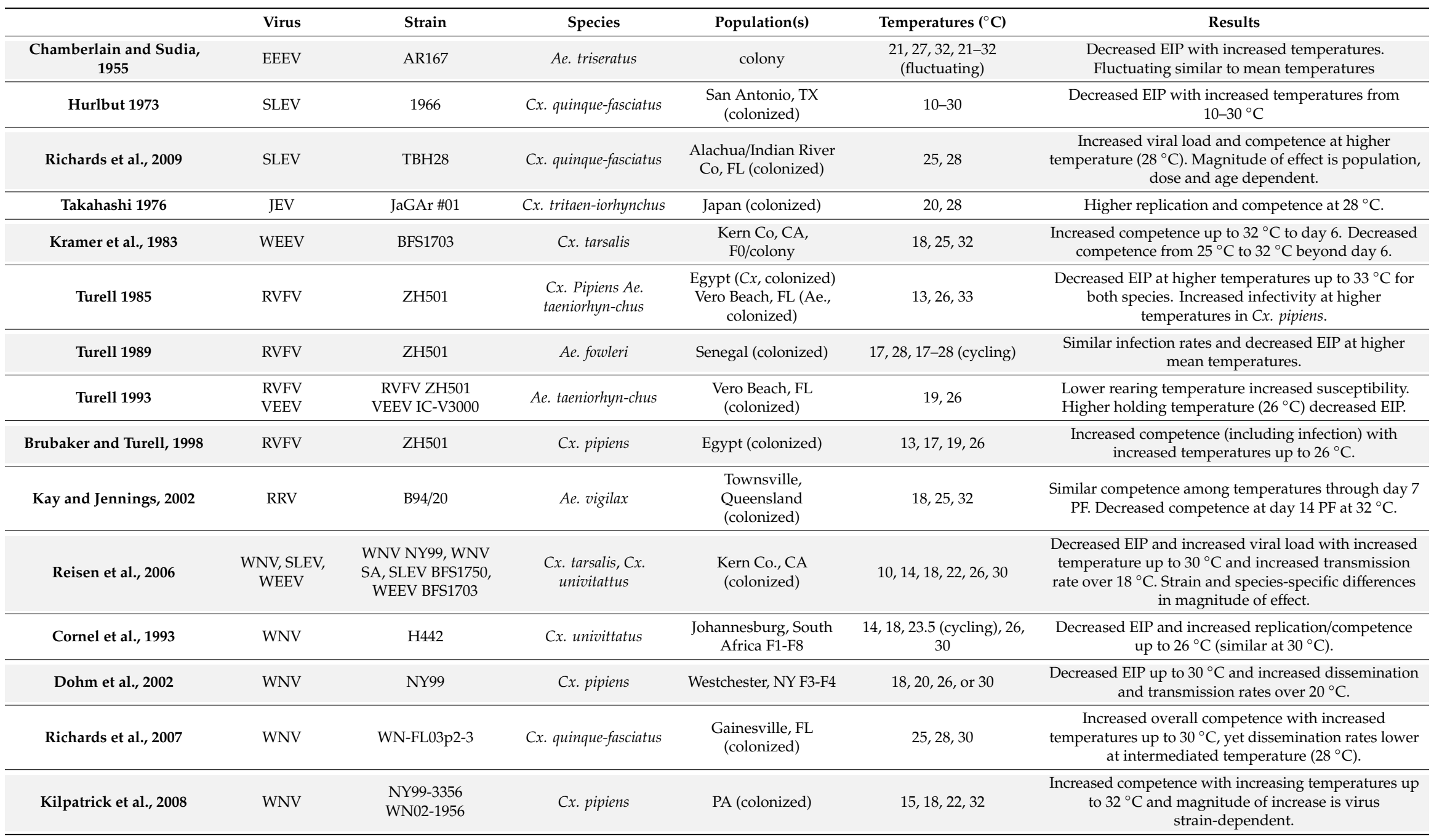


Table 2. Cont.

\begin{tabular}{|c|c|c|c|c|c|c|}
\hline & Virus & Strain & Species & Population(s) & Temperatures $\left({ }^{\circ} \mathrm{C}\right)$ & Results \\
\hline Anderson et al., 2010 & WNV & FL03p2-3 & Cx. quinque-fasciatus & $\begin{array}{l}\text { Gainesville, FL } \\
\text { (colonized) }\end{array}$ & 25,28 & $\begin{array}{l}\text { Increased viral load and vector competence at } 28^{\circ} \mathrm{C} \text { at } \\
\text { high and low virus dose. }\end{array}$ \\
\hline Danforth et al., 2015 & WNV & $\begin{array}{l}\text { NY99/COAV03, } \\
\text { KERN11 }\end{array}$ & $C x$. tarsalis & $\begin{array}{l}\text { Kern Co, CA } \\
\text { (colonized) }\end{array}$ & 22,30 & $\begin{array}{l}\text { Decreased EIP and increased transmission rates at } \\
\text { higher temperature }\left(30^{\circ} \mathrm{C}\right) \text {. No effect of viral strain } \\
\text { found. }\end{array}$ \\
\hline Vogels et al., 2016 & WNV & Lin. 2, Greece 2010 & $\begin{array}{l}\text { Cx. Pipiens } C x \text {. } \\
\text { Molestus hybrids }\end{array}$ & Netherlands, F3-F5 & $18,23,28$ & $\begin{array}{l}\text { Increased infection and transmission up to } 28^{\circ} \mathrm{C} \text { for } \mathrm{C} x \\
\text { pipiens and hybrids. Decreased competence from } 23^{\circ} \mathrm{C} \\
\text { to } 28^{\circ} \mathrm{C} \text { in } \mathrm{Cx} \text {. molestus. }\end{array}$ \\
\hline Danforth et al., 2016 & WNV & KERN11 & Cx. tarsalis & $\begin{array}{l}\text { Kern Co, CA } \\
\text { (colonized) }\end{array}$ & $\begin{array}{l}14.2,21.5,26.5,29 \text { (mean) } \\
11.0,13.5,10.1,14.2 \text { (DTR) }\end{array}$ & $\begin{array}{l}\text { Decreased EIP and increased transmissibility with } \\
\text { increased temperatures. Results statistically similar to } \\
\text { constant temperatures. }\end{array}$ \\
\hline Vogels et al., 2017 & WNV & Lin. 2, Greece 2010 & Cx. pipiens & $\begin{array}{l}\text { Netherlands, Italy, } \\
\text { F4-F6 }\end{array}$ & $18,23,28$ & $\begin{array}{l}\text { Increased infection and transmission from } 18^{\circ} \mathrm{C} \text { to } \\
23^{\circ} \mathrm{C} \text { in both populations and a further increase in } \\
\text { transmission in Italian population from } 23^{\circ} \mathrm{C} \text { to } 28^{\circ} \mathrm{C} \text {. }\end{array}$ \\
\hline
\end{tabular}


While previous studies have focused primarily on the direct impact of temperature on viral replication and competence in adult mosquitoes, there may also be indirect effects on vector competence resulting from variable aquatic temperatures during mosquito development. In general, effects of larval temperature are more apparent in Aedes spp. than Culex spp. Studies with Venezuelan equine encephalitis virus (VEEV), RVFV, chikungunya virus and Ross River virus (RRV) demonstrated an inverse relationship between larval rearing temperature and infectivity in Aedes spp. mosquitoes [36,45, 60], yet no effect was measured for RVFV in Cx. pipiens [49] Murray valley encephalitis virus (MVEV) in $C x$. annulirostris [61] or West Nile virus (WNV) in $C x$. tarsalis [62]. These relationships could be further complicated by additional environmental factors and larval density [63-65]. As temperature alters development time and mosquito size [62,66-68], and size has at times been associated with altered vector competence [69] this could be one important effect of temperature on competence, yet recent studies demonstrate that larval temperature can also significantly alter stress and immune gene expression [70], including influencing important proteins in the RNA interference pathway that can directly alter susceptibility in adult mosquitoes [71]. Additional mechanistic studies are needed to further probe how species and population-specific variability influences the impact of aquatic temperatures and other environmental factors on vector competence.

\section{Life History Traits and Blood Feeding Behavior}

Although experimental studies assessing the potential impact of temperature change on pathogen transmission have generally focused on vector competence, effects on development rates, longevity, gonotrophic cycle and blood feeding behavior are likely to have a larger influence on patterns and intensity of population-level transmission.

Increased aquatic temperatures accelerate immature development $[62,66,68,72-79]$, yet for vectors of enzootic arboviruses this effect is generally greater at lower temperature ranges (from $16.0^{\circ} \mathrm{C}-25.0$ ${ }^{\circ} \mathrm{C}$ ), as compared to increases over $25.0^{\circ} \mathrm{C}[62,66,72]$, and may be highly dependent on temperature fluctuation in addition to mean temperatures $[59,72,80]$. Although increased development rates in isolation would increase population size, this could be offset to some extent by increased immature and/or adult mortality, as well as decreased blood feeding, mating success, clutch size or hatch rates [66,72]. Ciota et al. found increased larval mortality for Culex restuans at higher temperatures $\left(24.0^{\circ} \mathrm{C}-32.0^{\circ} \mathrm{C}\right)$, but no effect of temperature on immature survival with field populations of $C x$. pipiens or $C x$. quinquefasciatus [66]. Conversely, Grech et al. found a positive correlation between temperature and immature survival of $C x$. quinquefasciatus from $16.6^{\circ} \mathrm{C}$ to $25.2{ }^{\circ} \mathrm{C}$ [75], and a study with Egyptian $C x$. pipiens found decreased survival at simulated mean summer-autumn temperatures (mean $30.2^{\circ} \mathrm{C}$ ) relative to winter-spring temperatures (mean $20.5^{\circ} \mathrm{C}$ ) [81]. Others have found a unimodal effect of temperature, with optimal immature survival of $C x$. quinquefasciatus measured at $23.0^{\circ} \mathrm{C}$ [73], $\mathrm{Cx}$. pipiens form molestus at $25.0^{\circ} \mathrm{C}$ [72] and $\mathrm{C} x$. eduardoi at $28.1^{\circ} \mathrm{C}$ [78].

Studies of adult longevity and temperature are generally in better agreement, with decreased longevity at higher temperatures in ranges from $15.0^{\circ} \mathrm{C}$ to $32.0^{\circ} \mathrm{C}[72,73,81-83]$ and thermal thresholds for Culex survival generally estimated at $\sim 34.0^{\circ} \mathrm{C}[72,78]$. The effect of temperature on the Aedes species may be less pronounced, although studies with enzootic vectors such as Ae. triseriatus and Ae. japonicus are limited $[84,85]$. As with vector competence, studies with Ae. albopictus and Ae. aegypti are more numerous and have generally demonstrated unimodal relationships for temperature and longevity, with higher optimal temperatures and thermal thresholds than enzootic vectors which generally originate from more temperate areas $[54,86,87]$.

Blood feeding frequency, on a population level, should increase with development time and temperature, yet this may not always be the case if mating and/or host seeking success is negatively influenced by rising temperatures. Studies with $C x$. pipiens and $C x$. quinquefasciatus found an increased likelihood of blood feeding with increased temperatures from $10{ }^{\circ} \mathrm{C}$ to $28{ }^{\circ} \mathrm{C}$ [88,89], yet feeding rates could decrease at higher temperatures [66]. Differences at lower temperatures are additionally influenced by photoperiod, demonstrating that multiple environmental cues influence diapause in 
some mosquitoes that overwinter as adults [89]. No effect of temperature on blood feeding probability of Ae. triseriatus from $25.2{ }^{\circ} \mathrm{C}$ to $32.2{ }^{\circ} \mathrm{C}$ was found [85], yet extreme temperatures $\left(<20.0^{\circ} \mathrm{C}\right.$ and $>35.0^{\circ} \mathrm{C}$ ) have been also been shown to decrease mating [90], and could therefore negatively impact feeding frequencies.

As with vector competence, effects of temperature on life-history traits have been found to be both species and population-dependent $[66,83,88,91-93]$. The variability in experimental results demonstrates that making broad conclusions regarding the potential effect of rising temperatures on vectorial capacity is difficult. One general trend that is apparent is that optimal temperatures for vector fitness (i.e., temperatures at which population size is maximized) are generally lower than optimal temperatures for pathogens (temperatures at which competence and extrinsic incubation rates are maximized). Studies modeling transmissibility need to consider the differential effects of temperature on all aspects of vectorial capacity. There are additional caveats to these experimental studies that need to be considered. First, experimental studies, even those that have utilized fluctuating temperatures, still fail to account for the range of fluctuation of temperature and numerous other potentially critical dynamic environmental factors. Additionally, a number of studies have demonstrated that enzootic arboviruses including WNV, Eastern equine encephalitis virus (EEEV) and La Crosse Virus (LACV) can have significant impacts on mosquito longevity [50,94-96], fecundity [97] and blood feeding behavior [98]. Whether or not such effects are variable at different temperatures or with different viral strains has not been well studied but is suggested $[83,96]$. Lastly, the extensive variability on both the individual and population level demonstrates that significant plasticity exists in response to changing temperatures that likely has a genetic basis. This suggests that studies with current populations may be inept representations of future populations, which theoretically could acquire increased fitness at higher temperatures as a result of adaptive evolution.

\section{Vector and Host Distributions}

Temperature influences the distribution of vectors $[99,100]$ and hosts $[101,102]$ (Table 1). Mosquito vector distribution information is available for species within the USA [103,104], Europe [105], and globally [106,107]. Host distribution information is also available [108-110]. Birds are major hosts for many of the arboviruses (Table 1) and the distribution of avian hosts is very well understood in the USA [111-113] and relatively so globally [113].

Temperature effects on mosquitoes are generally thought to be unimodal [3], although the location of the mode varies by species [114,115]. For example, $C x$ annulirostris, a major vector for RRV, had increasing abundance with increasing temperature up to $32^{\circ} \mathrm{C}$ (minimum $\sim 10^{\circ} \mathrm{C}$ ), while $\mathrm{C} x$. australis, another prevalent mosquito species in the same area, had peak abundance at lower temperatures ( $\mathrm{min}$ $6{ }^{\circ} \mathrm{C}$ ), but peak abundances were lower than for $C x$. annulirostris [114]. Similarly, while increased temperatures have been shown to increase $C x$. pipiens, in some of the same regions, they have been shown to decrease populations of $C x$. restuans, involved in early-season amplification of WNV [115]. Vector distribution can also lead to non-intuitive patterns of disease outbreak. For example, seasonal activity of RRV in Australia for a given vector species is later as one progresses from north to south. However, seasonal activity begins earlier in some southern areas due to the presence of a vector species that is active at lower temperatures [116]. Therefore, the direction of temperature effects vary by species and by the specific study site within a species range (e.g., [116,117]).

Consequently, in epizootic areas and endemic areas on the low side of the temperature range for arboviruses, an increase in temperature has often been associated with an increase in major vector populations. For example, increased temperatures have been associated with increased abundance of Cx. pipiens $[115,118-121]$, a major vector for WNV. Increased temperatures have also been associated with an extended $C x$. pipiens season [121]. The northern limit of EEEV is likely temperature limited due to lack of availability of suitable overwintering sites. Cs. melanura, the main vector for EEEV, is active at low temperatures $\left(1-5^{\circ} \mathrm{C}\right)[122]$, but requires liquid water in order to overwinter as larvae 
(typically in aquatic habitat underneath trees) [123]. In Botswana, seasonal temperature was important for $C x$. pipens dynamics [124].

In regions with higher average temperatures, no effect of temperature variation may be detected, or effects may be mixed. For example, in Senegal, three major RVFV vector species increased in abundance with increasing temperature [125], but increased temperatures were associated with decreased RVFV hotspot risk [126]. Cx. poicilipes in this region was also found to increase with increased minimum temperature but decreased with increased maximum temperature [127]. Cx pipiens distribution in the Middle East and North Africa was primarily driven by human population density and land cover, but not by temperature or rainfall [128], although a local study in Saudi Arabia found temperature was an important predictor for RVFV vector Cx. tritaeniorhynchus [129].

Vector distributions have been explicitly modeled through species distribution modeling (SDM) (Reviewed in [130] and Table S2 of [3]). The geographic scope of these models is highly variable, with the global distribution of Ae. aegypti and Ae. albopictus having been repeatedly studied [107,131-140]. Cx. quinquefasciatus has also been studied globally $[132,141]$. Other species have global distributions (e.g., Cx. pipiens [142]), but to our knowledge have only been modeled within continents [143]. The capacity of vectors to adapt to local conditions have also been evaluated using a species distribution modeling (SDM) approach. The accuracy of SDMs has been evaluated using Ae. albopictus distribution for each continent to predict its distribution on other continents [140]. Only moderate matches between the predicted and actual distribution were found, suggesting that SDMs do not capture all factors of relevance, which is consistent with critiques of these approaches [144]. Mathematical models have also been used to model vector population dynamics [130].

Both vector and host ranges are forecast to shift further under future climate change. $C x$. pipiens, a major vector for $\mathrm{WNV}$, is already present in new locations [145], and is projected to expand its range further in Canada, especially under a high-greenhouse-gas emission scenario [143]. The distribution of $C x$. quinquefasciatus in California and Florida is predicted to decline in mid-to-late summer, but may have increased populations during the winter [146], and range shifts are also anticipated under climate change [141]. Broad analyses indicating expected range shifts due to climate change have been performed [147].

\section{Viral Distribution}

A wide variety of models have been used to model temperature effects on arboviruses, including Machine Learning techniques [148-150], a real-time Bayesian Ensemble Adjustment Kalman Filter method [151], spatiotemporal Bayesian models [152,153], generalized linear models [150,154-157], case-crossover approaches [158], seasonal autoregressive models [159,160], $R_{0}$ models [3], and Susceptible-Infectious-Recovered (SIR) and Susceptible-Exposed-Infectious-Recovered (SEIR) models [3,124,151,161-167]. West Nile virus is by far the most studied enzootic arbovirus (Table 3). Models have been reviewed for WNV [15,149,163,168], Japanese encephalitis virus (JEV) $[15,16,20]$, RVFV [14,15], RRV [7], and Barmah forest virus (BFV) [7,169,170]. Modeling studies on temperature for remaining viruses include: EEEV [3,171], LACV [13], MVEV [3], Sindbis virus (SINV) [3,172,173], St. Louis encephalitis virus (SLEV) [3,174], and Western equine encephalitis virus (WEEV) ([174-176] and citations therein, [3]). Note that modeling studies that did not include temperature were omitted here (e.g., EEEV: $[177,178])$. The treatment of temperature in environmental models varies substantially, from simple statistical correlations to complex mechanistic models. Even mechanistic models vary in complexity. On one end, temperature based on mean climatology has been used in a simple way to correct for geographic differences [151]. At the other end, multiple life-history traits have been synthesized into a single modeling approach [3]. 
Table 3. Literature search results that include individual viruses and temperature as keywords, 1983-2019.

\begin{tabular}{|c|c|c|c|c|}
\hline Virus $^{1}$ & \# Studies Found ${ }^{2}$ & $\begin{array}{l}\text { \# Studies + } \\
\text { Temperature }\end{array}$ & $\begin{array}{l}\% \text { of Research on } \\
\text { Temperature }\end{array}$ & $\begin{array}{c}\text { \% of ALL Found } \\
\text { Studies on } \\
\text { Temperature }\end{array}$ \\
\hline EEEV & 608 & 34 & 6 & 3 \\
\hline WEEV & 433 & 45 & 10 & 5 \\
\hline SINV & $2873^{4}$ & $195^{4}$ & 7 & 20 \\
\hline RRV & 843 & 70 & 8 & 7 \\
\hline BFV & 178 & 19 & 11 & 2 \\
\hline VEEV & 955 & 38 & 4 & 4 \\
\hline MAV & 205 & 12 & 6 & 1 \\
\hline LACV & 573 & 27 & 5 & 3 \\
\hline RVFV & 1648 & 97 & 6 & 10 \\
\hline JEV & 5426 & 137 & 3 & 14 \\
\hline MVEV & 291 & 9 & 3 & 1 \\
\hline SLEV $^{3}$ & 687 & 49 & 7 & 5 \\
\hline WNV & 11310 & 526 & 5 & 53 \\
\hline
\end{tabular}

${ }^{1}$ Virus abbreviations defined in Table $1 ;{ }^{2}$ literature search performed on 4 October, 2019. All others performed on 23 May, 2019; ${ }^{3}$ search term: (Saint OR St) Louis Encephalitis virus; ${ }^{4}$ most of the SINV results found here were excluded from the review as they focused on molecular techniques unrelated to the virus in the environment.

Despite the variety of environmental models used and the range of arboviruses examined, temperature effects have been relatively consistent. Within the main portion of the arboviruses' range and along the cooler edge, an increase in temperature is typically associated with an increase in arboviral activity. For example, WNV infection rates north of $30^{\circ} \mathrm{N}$, have been associated with increased temperatures $[118,150,154-156,158,159,179-193]$. An increase with increasing temperatures has often been found for JEV as well [16,194-199], as has SLEV [200,201]. WEEV was associated with increased risk with increased temperature in California's Central Valley [176]. WEEV and SLEV have both been associated with temperatures greater than $29^{\circ} \mathrm{C}$ [202]. JEV incidence increased with minimum and maximum temperatures in Jieshou county, China [203]. Temperatures above thresholds of $25.2{ }^{\circ} \mathrm{C}$ for maximum temperature and $21.0^{\circ} \mathrm{C}$ for minimum temperature were associated with JEV in a temperate city in China [196]. Another study across all of China (approximately $50 \%$ of JEV cases worldwide), found JEV to increase with increasing minimum temperature, but it increased and then decreased with increasing maximum temperature [204]. Using minimum temperature, human population density, mean temperatures, and elevation, they were able to identify a high risk area with $6 \%$ of China's land area but $60 \%$ of JEV cases in China [204]. A similar pattern has been observed south of the tropics, where there is concern that the Kunjin strain of WNV will shift further south in Australia [205,206].

Low temperatures have been found to be limiting the distribution of many arboviruses. Low temperatures are generally thought to be limiting WNV expansion northward [25,32,143,207-211]. Further, high temperatures have been observed to aid in the establishment of arboviruses. For example, WNV often invaded new locations following heatwaves [44], but once established no longer required such high temperatures to persist $[27,212]$. Indeed, simulations found that temperature was more important in WNV establishment than mosquito population composition (i.e., biotype ratio of $C x$. pipiens), fraction of hosts that are birds, and the mosquito-to-host ratio [32]. At low temperatures $\left(18^{\circ} \mathrm{C}\right)$, mosquito-to-host ratio has a greater influence on WNV establishment [32]. Similarly, amplification of SLEV was estimated to stop at $17^{\circ} \mathrm{C}[40,202]$ although the virus has still been detected in female mosquitoes during winter and spring when temperatures were between $11-15^{\circ} \mathrm{C}$. SLEV has also been predicted to expand further northward due to increased temperature suitability [213] as SLEV outbreaks have generally occurred at or below the $21^{\circ} \mathrm{C}$ isotherm [214].

A role of temperature has also been observed within the tropics. JEV vector abundance has also been shown to increase with increasing temperature in India [215,216] but see [217] for the same study 
region where no significant correlation with temperature and JEV infection rate was found. Increased minimum temperature with a 6-month lag was associated with increased JEV cases in Malaysia [218].

However, increased temperatures may cause decreases in arbovirus activity in hotter portions of their range. For instance, high temperatures have been predicted to limit WNV in subtropical regions [117]. WEEV risk has been predicted [213] and observed [176] to decrease in the southern portion of its range with an increase in temperature. $C x$. tarsalis is able to clear WEEV infections at $32{ }^{\circ} \mathrm{C}$ compared to 18 and $25^{\circ} \mathrm{C}$ [213]. Transovarial transmission in $\mathrm{C} x$. tarsalis is increased for SLEV at $18^{\circ} \mathrm{C}$ relative to $27^{\circ} \mathrm{C}$ [219]. Data on $\mathrm{C}$. quinquefasciatus suggests that WNV will decline in some portions of its Southern range with increasing temperatures $[117,146]$. Maximum temperature was negatively associated with seroprevalence of RVFV, although there was a strong trend towards an increase in seroprevalence with increasing night-time (minimum) temperature [220]. A large MVEV outbreak occurred during 2010/2011 due to low temperatures and high rainfall [221].

Within the normal range of some viruses, environmental temperatures were not found to be the main limiting factor. For example, rainfall and tides are the main environmental predictors for RRV [7] and similarly RVFV is strongly tied to rainfall $[14,222,223]$. Rainfall was more strongly associated with EEEV than temperature in Rhode Island, USA [171]. Rice fields, swine production, and percent of humans and swine vaccinated were more important for JEV in some regions [17]. On the island of Mayotte, where temperatures were suitable for RVFV, the import of an animal infected with RVFV was the most important risk factor [224]. No direct temperature relationships were detected for SINV in South Africa [173]. A study of seasonal and meteorological models aggregated by state in Australia found relatively small improvements of adding weather variables for RRV and BFV, with the largest improvements due to lagged variables [157]. Similarly, in Queensland, weather variables were not found to predict RRV [225].

Statistical methods can also influence whether or not temperature is significantly related to disease in a region. For example, temperature was correlated with JEV in Nepal, but was not retained in a final model when other covariates were considered (precipitation, the percentage of irrigated land, the percentage of grassland cover, and the pig-to-human ratio) [226]. Therefore, models may show a temperature effect, but the effect may disappear when another relevant covariate is included.

\subsection{Indirect Effects}

Beyond direct temperature effects, temperature can influence arboviruses indirectly through interactions with other variables. Drought has been found to be important in the amplification of Flaviviruses, with a strong association between drought and drier conditions and WNV [150,180,227-231] and SLEV [174,201,232,233]. Increased snow depth was predictive of increased SINV in Finland [172], suggesting an indirect role of temperature on this virus. SLEV was found to increase indirectly with low temperatures [234]: winter freezes in Florida were associated with increased avian breeding success that resulted in a larger number of susceptible hosts [235].

\subsection{Climate Change}

Many arboviruses are expected to shift poleward under climate change, due to increasing temperatures. Migratory birds with antibodies to WNV already arrive in northern Europe (Sweden) [236], demonstrating that dispersal is not limiting arboviral activity in these locations. WNV is expected to increase in Europe, even in locations where it is already present, under future climate change [209], and to increase in range and intensity in Canadian prairies under a range of future climate conditions [211]. Increased drought expected under climate change has the potential to triple WNV cases over a 30-year time frame in locations where there is low human immunity [229]. In contrast, increased rainfall has been predicted to lead to decreased WNV in some regions despite temperature increases [208]. Increasing temperatures associated with climate change may have facilitated arboviral spread up elevation gradients. For example, JEV has recently expanded into Tibet where it was formerly thought to be excluded due to high elevation [237]. RRV is expected to increase in temperate areas, but 
decrease in tropical areas where it is endemic due to increases in temperature [167]. In contrast, MVEV is predicted to decrease in summer and autumn in Western Australia due to higher temperatures decreasing vector survival [238]. Risk for BFV has also been assessed and was not expected to change much when both temperature and rainfall were included in the model [169].

\subsection{Case Study: Season-Specific Effects in West Nile Virus in Temperate Regions}

The role of temperature across seasons has been well-studied for WNV. While transmission season temperatures are clearly important, temperatures in the non-transmission seasons can also affect viral dynamics.

\subsubsection{Winter Temperatures}

Warmer winter temperatures have been associated with WNV across the continental US [155,179], Russia [186,187] and in localized studies [160,191]. Low temperatures are sufficient to halt viral replication (e.g., $14.3^{\circ} \mathrm{C}$ or below for WNV in $C x$. tarsalis [44]), although infections in mosquitoes persist at these low temperatures and replication may resume in the spring $[44,239]$. Thus, it is expected that winter temperatures are acting on vector populations. Other modes of overwintering (e.g., within birds, reviewed in $[240,241]$ ) could provide increased capacity for seasonal maintenance that are less sensitive to temperature variation.

\subsubsection{Spring Temperatures}

Warm and dry springs have been associated with WNV [154], especially maximum temperatures, which are likely associated with increased early amplification [149]. Temperature in May and June were linked to WNV in Russia [186]. Early-season temperatures were predictive of human cases later in the year in South Dakota [190].

\subsubsection{Summer Temperatures}

Above average summer temperatures likely contributed to WNV epidemics in 2002-2004 [44] and hot dry summers were also identified as associated with WNV foci in Connecticut, while warm wet summers were associated with more distributed cases of WNV [242]. Minimum summer temperature was found to predict human and mosquito cases in New York and Connecticut [149]. Increased temperatures at a two-week lag interval were associated with WNV in Suffolk County, NY [152] and Nassau County, NY [153]. August and September temperatures were associated with increased WNV incidence in Russia [186]. Increased summer temperatures were associated with West Nile fever in Europe $[184,189]$. In Romania, temperatures twenty days earlier were found to increase WNV infection rates [227]. High temperature anomalies in July were linked to WNV outbreaks in Europe [184,243]. In contrast, in West Texas, a dry and cool summer following a wet spring was associated with increased WNV cases [244]. In locations with high summer temperatures (i.e., deserts), habitat suitability for WNV may be low during the summer [245]. In South Africa, an increase in minimum summer temperature decreased WNV infection rates [173]. Similarly, summer temperatures have also been linked to JEV in Japan [195].

\subsubsection{Fall Temperatures}

Dropping temperatures in the fall have the potential to end the West Nile virus season. However, late season temperatures associated with the end of the WNV season have generally not been retained in final models of WNV risk [e.g., 149]. One explanation for this is that changes in host behavior and abundance are likely more important than temperature at this time of year [246]. 


\subsection{Case Study: Barmah Forest Virus}

Temperature relationships for BFV are scale-dependent, but generally risk of BFV increases with increasing temperatures. BFV was found to increase with increased minimum temperature based on 0-, 2-, 3-, 4-, and 5-month lags in Queensland, Australia (using seasonal differencing to control for seasonal effects) [247], and with increasing maximum temperature [248] (note exact attribution is difficult as minimum and maximum temperature are strongly correlated in the region, Spearman correlation coefficient of 0.93 ). BFV risk increased with increasing minimum temperatures in coastal regions [169]. BFV risk was decreased with increasing minimum temperature at the scale of the entire state of Queensland [170], but this effect could be due to a contrast between interior and coastal areas rather than an inconsistent temperature effect (i.e., Simpson's paradox $[249,250])$.

\subsection{Case Study: Ross River Virus}

RRV is an excellent example of a virus demonstrating a temperature optimum [3], although a number of studies from different geographic regions have not reported an effect of temperature on RRV after controlling for other variables [251-254]. A study summarizing 100 years of epidemics found that relationships with temperatures varied by region, with an increase in minimum temperatures being associated with RRV in Southern Australia, an increase in RRV associated with a decrease in maximum temperatures in arid parts of Australia, and no strong relationship in tropical northern Australia, where temperatures are routinely suitable for this virus [8]. At a regional scale (defined by cluster analysis), the RRV risk decreased with increasing spring minimum temperatures in the northernmost region (closest to equator), while in the southernmost (poleward) region, RRV risk increased with increasing spring minimum and maximum temperatures, with two other regions showing no effect of temperature [225]. Similarly, in Southern Australia, RRV infections increased with either increasing monthly mean minimum or maximum temperatures [255] and temperature increased RRV risk in Tasmania [256]. Temperature was included in a model used to forecast RRV risk 1-5 weeks in advance in Western Australia [257]. Risk of RRV increased with increasing minimum temperature, except in one area (Capel, in SW Australia) [257]. Risk also generally increased with increasing maximum temperature, but decreased in Capel [257], and showed no effect in two other locations.

Temperature results in Queensland in northwest Australia have been variable, and this may be due to the stronger effects of rainfall and tides [258]. One study found that RRV incidence increased by $2.4 \%$ for each $1{ }^{\circ} \mathrm{C}$ increase (including a statistical correction for season) [259]. Temperature was not significantly related to RRV in the city of Brisbane [260] in one study, but another study found a negative effect of maximum temperature there [261]. Maximum and minimum temperature were associated with RRV risk along the coast, but not inland in another study [262]. Maximum temperature was weakly positively correlated with RRV in Townsville after accounting for other variables [263].

\subsection{Case Study: Rift Valley Fever Virus}

Temperature effects have also been detected in viruses where other factors have been shown to be the main determinants of viral dynamics. Rainfall and vegetation have been found to be most predictive of RVFV [264] and RVFV in south and east Africa was successfully predicted without consideration of land surface temperature [265]. However, a mechanistic model based on water temperature and surface area was used to examine a range of conditions theoretically expected to be favorable to RVFV persistence and outbreaks [164] and in Kenya, minimum temperature was among the significant variables included in a RVFV early-warning system [266]. Temperature factored into a mechanistic model for RVFV in East Africa [267]. Temperature and precipitation effects were also included in a SEIR model of RVFV in Tanzania, where an increased risk at low temperatures was found, despite an increase in overall risk under climate change ([165], but see [268] where no effect of temperature was observed). Cooler-than-normal temperatures regionally $\left(\sim 30^{\circ} \mathrm{C}\right.$ compared to $\left.\sim 40^{\circ} \mathrm{C}\right)$ and heavy rainfall were associated with RVFV in South Africa in 2010/2011 [221], but note that spatially, epidemic 
outbreaks were most likely to occur in regions with temperature $>32{ }^{\circ} \mathrm{C}$, and increased risk from $25-32$ ${ }^{\circ} \mathrm{C}$ relative to temperatures $<25^{\circ} \mathrm{C}$ [269]. Temperature was also included in a discriminant analysis of RVFV in South Africa [270].

Temperature has also played a strong role in risk modeling for new locations. Temperatures associated with mosquito development were used in modeling suitable locations in North Africa [271] and Spain [272] for RVFV. Specifically, a minimum of $14{ }^{\circ} \mathrm{C}$ and a maximum of $40{ }^{\circ} \mathrm{C}$ were used, with an optimum of $28-32{ }^{\circ} \mathrm{C}$ for enzootic suitability, and a linearly increasing risk for epizootic transmission. Extrinsic incubation period and gonotropic period both decreased with increasing temperature (increasing viral risk) in a model of locations suitable for RVFV in California, USA [166]. The model found that a RVFV outbreak was possible in all months except December and January. A temperature-based model for the continental USA found that the number of risk days ranged from 0 in the far north to 325 in Florida [273].

\section{Concluding Remarks and Future Directions}

Thermal biology is emerging as a trait-based approach to studying temperature effects, especially for arboviruses [3]. Two patterns in temperature relationships among arboviruses were revealed: in some viruses, a strong role of temperature was clear across the virus' range, while for others, temperature was more important in setting the virus' range, but not in governing dynamics within that range. For example, WNV frequently increased with increasing temperature, even in locations where it was endemic. In contrast, RVFV generally did not show strong temperature effects where the virus was endemic.

The relationship between temperature and viral transmission may be complex due to the variety of influences on different aspects of the ecology and biology of vectors, hosts, and viruses [3]. The fact that temperatures effects can vary at multiple time scales (i.e., within days and across seasons) can further complicate these relationships. Diurnal variations due to non-linear temperature relationships are important [57], have been observed for WNV [183], and can be accounted for in analyses of arboviruses [3]. Spatial variation in temperature is also important, and is not well represented on fine scales (i.e., microclimatic variation) by gridded temperature products $[274,275]$. This can lead to underestimation of vector-borne disease risk in some habitats and locations [276].

Where arboviruses are emerging, more refined spatial and temporal data could improve early warning forecasting systems. High-quality, publicly available temperature data sets exist, but vector species abundances and locations and virus infection rates need to be more publicly available in accessible Geographic Information System (GIS) formats. Improved knowledge of vector and host distribution would also be instrumental in improved forecasts of expected changes under climate change. Host-vector interactions are additionally important, and the degree to which host choice depends on temperature is also worthy of study. Host choice in Cs. melanura, for example, has also been found to be temperature dependent [277], however temperature co-varied with season, which needs to be controlled for in future studies. Temperature effects can vary by vector species and even within populations of a single species. Vector and host populations can evolve and adapt, and temperature will likely have significant effects on both the rate and trajectory of viral evolution. For this reason, models need to be informed by experimental studies that consider not just how changing temperatures interact with current biological systems, but also future biological systems. Further, the degree to which temperature relationships interact with other environmental variables (e.g., precipitation, insecticide resistance, vaccine development) should be considered. Defining these complex and nuanced relationships over appropriate temporal and geographic scales, while daunting, is critical if we are to accurately define how climate change will alter the transmission dynamics of mosquito-borne viruses.

Author Contributions: Conceptualization, A.T.C.; methodology, A.T.C., A.C.K.; writing-original draft preparation, A.T.C., A.C.K.; writing-review and editing, A.T.C., A.C.K.; supervision, A.T.C. 
Funding: This publication was supported by cooperative agreement 1U01CK000509-01, funded by the Centers for Disease Control and Prevention. Its contents are solely the responsibility of the authors and do not necessarily represent the official views of the Centers for Disease Control and Prevention or the Department of Health and Human Services.

Acknowledgments: We thank the Northeast Regional Center of Excellence in Vector-Borne Disease.

Conflicts of Interest: The authors declare no conflicts of interest. The funders had no role in the design of the study; in the collection, analyses, or interpretation of data; in the writing of the manuscript, or in the decision to publish the results.

\section{References}

1. Pachauri, R.K.; Allen, M.R.; Barros, V.R.; Broome, J.; Cramer, W.; Christ, R.; Church, J.A.; Clarke, L.; Dahe, Q.; Dasgupta, P.; et al. Contribution of Working Groups I, II and III to the Fifth Assessment Report of the Intergovernmental Panel on Climate Change. In IPCC Climate Change 2014: Synthesis Report; Pachauri, R.K., Meyer, L.A., Eds.; IPCC: Geneva, Switzerland, 2014; p. 151.

2. Caminade, C.; McIntyre, K.M.; Jones, A.E. Impact of recent and future climate change on vector-borne diseases. Ann. N. Y. Acad. Sci. 2019, 1436, 157-173. [CrossRef] [PubMed]

3. Mordecai, E.A.; Caldwell, J.M.; Grossman, M.K.; Lippi, C.A.; Johnson, L.R.; Neira, M.; Rohr, J.R.; Ryan, S.J.; Savage, V.; Shocket, M.S. Thermal biology of mosquito-borne disease. Ecol. Lett. 2019, 22, 1690-1708. [CrossRef] [PubMed]

4. Lindsey, N.P.; Staples, J.E.; Fischer, M. Eastern equine encephalitis virus in the United States, 2003-2016. Am. J. Trop. Med. Hyg. 2018, 98, 1472-1477. [CrossRef]

5. Reisen, W.; Monath, T. Western equine encephalomyelitis. In The Arboviruses: Epidemiology and Ecology; CRC Press: Boca Raton, FL, USA, 1989; Volume 5, pp. 89-137.

6. Suhrbier, A.; Jaffar-Bandjee, M.-C.; Gasque, P. Arthritogenic alphaviruses-An overview. Nat. Rev. Rheumatol. 2012, 8, 420-429. [CrossRef]

7. Jacups, S.P.; Whelan, P.I.; Currie, B.J. Ross River virus and Barmah Forest virus infections: A review of history, ecology, and predictive models, with implications for tropical northern Australia. Vector Borne Zoonotic Dis. 2008, 8, 283-297. [CrossRef]

8. Kelly-Hope, L.; Purdie, D.; Kay, B. Ross River virus disease in Australia, 1886-1998, with analysis of risk factors associated with outbreaks. J. Med. Entomol. 2004, 41, 133-150. [CrossRef]

9. Tong, S.; Dale, P.; Nicholls, N.; Mackenzie, J.S.; Wolff, R.; McMichael, A.J. Climate Variability, Social and Environmental Factors, and Ross River Virus Transmission: Research Development and Future Research Needs. Environ. Health Perspect. 2008, 116, 1591-1597. [CrossRef]

10. Yu, W.; Dale, P.; Turner, L.; Tong, S. Projecting the impact of climate change on the transmission of Ross River virus: methodological challenges and research needs. Epidemiol. Infect. 2014, 142, 2013-2023. [CrossRef]

11. Weaver, S.C.; Ferro, C.; Barrera, R.; Boshell, J.; Navarro, J.-C. Venezuelan equine encephalitis. Annu. Rev. Entomol. 2004, 49, 141-174. [CrossRef]

12. Weaver, S.C.; Reisen, W.K. Present and future arboviral threats. Aniviral Res. 2010, 85, 328-345. [CrossRef]

13. Haddow, A.D.; Odoi, A. The incidence risk, clustering, and clinical presentation of La Crosse virus infections in the eastern United States, 2003-2007. PLoS ONE 2009, 4, e6145. [CrossRef] [PubMed]

14. Linthicum, K.J.; Britch, S.C.; Anyamba, A. Rift Valley fever: an emerging mosquito-borne disease. Annu. Rev. Entomol 2016, 61, 395-415. [CrossRef] [PubMed]

15. Esser, H.J.; Mogling, R.; Cleton, N.B.; van der Jeugd, H.; Sprong, H.; Stroo, A.; Koopmans, M.P.G.; de Boer, W.F.; Reusken, C.B.E.M. Risk factors associated with sustained circulation of six zoonotic arboviruses: A systematic review for selection of surveillance sites in non-endemic areas. Parasit Vectors 2019, 12. [CrossRef] [PubMed]

16. Bai, L.; Morton, L.C.; Liu, Q. Climate change and mosquito-borne diseases in China: a review. Global. Health 2013, 9, 10. [CrossRef]

17. Erlanger, T.E.; Weiss, S.; Keiser, J.; Utzinger, J.; Wiedenmayer, K. Past, present, and future of Japanese encephalitis. Emerg. Infect. Dis 2009, 15, 1-7. [CrossRef]

18. Misra, U.K.; Kalita, J. Overview: Japanese encephalitis. Prog. Neurobiol. 2010, 91, 108-120. [CrossRef]

19. Rosen, L. The Natural History of Japanese Encephalitis Virus. Annu. Rev. Microbiol. 1986, 40, $395-414$. [CrossRef] 
20. Yi, L.; Xu, X.; Ge, W.; Xue, H.; Li, J.; Li, D.; Wang, C.; Wu, H.; Liu, X.; Zheng, D.; et al. The impact of climate variability on infectious disease transmission in China: Current knowledge and further directions. Environ. Res. 2019, 173, 255-261. [CrossRef]

21. Selvey, L.A.; Dailey, L.; Lindsay, M.; Armstrong, P.; Tobin, S.; Koehler, A.P.; Markey, P.G.; Smith, D.W. The Changing Epidemiology of Murray Valley Encephalitis in Australia: The 2011 Outbreak and a Review of the Literature. PLoS Negl. Trop. Dis. 2014, 8, e2656. [CrossRef]

22. Luby, J.P. St. Louis Encephalitis. Epidemiol. Rev. 1979, 1, 55-73. [CrossRef]

23. Day, J.F. Predicting St. Louis Encephalitis Virus Epidemics: Lessons from Recent, and Not So Recent, Outbreaks. Annu. Rev. Entomol. 2001, 46, 111-138. [CrossRef] [PubMed]

24. Hubalek, Z.; Halouzka, J. West Nile fever-A reemerging mosquito-borne viral disease in Europe. Emerg. Infect. Dis. 1999, 5, 643-650. [CrossRef] [PubMed]

25. Reisen, W.K. Ecology of West Nile virus in North America. Viruses 2013, 5, 2079-2105. [CrossRef]

26. Chancey, C.; Grinev, A.; Volkova, E.; Rios, M. The global ecology and epidemiology of West Nile virus. BioMed. Res. Int. 2015, 2015. [CrossRef]

27. Paz, S. Climate change impacts on West Nile virus transmission in a global context. Phil. Trans. R. Soc. B 2015, 370, 20130561. [CrossRef]

28. Franz, A.; Kantor, A.; Passarelli, A.; Clem, R. Tissue barriers to arbovirus infection in mosquitoes. Viruses 2015, 7, 3741-3767. [CrossRef]

29. Hardy, J.L.; Houk, E.J.; Kramer, L.D.; Reeves, W.C. Intrinsic factors affecting vector competence of mosquitoes for arboviruses. Annu. Rev. Entomol. 1983, 28, 229-262. [CrossRef]

30. Richards, S.L.; Lord, C.C.; Pesko, K.; Tabachnick, W.J. Environmental and biological factors influencing Culex pipiens quinquefasciatus Say (Diptera: Culicidae) vector competence for Saint Louis encephalitis virus. Am. J. Trop. Med. Hyg. 2009, 81, 264-272. [CrossRef]

31. Danforth, M.E.; Reisen, W.K.; Barker, C.M. Extrinsic incubation rate is not accelerated in recent California strains of West Nile virus in Culex tarsalis (Diptera: Culicidae). J. Med. Entomol. 2015, 52, 1083-1089. [CrossRef]

32. Vogels, C.B.F.; Hartemink, N.; Koenraadt, C.J.M. Modelling West Nile virus transmission risk in Europe: effect of temperature and mosquito biotypes on the basic reproduction number. Sci. Rep. 2017, 7, 5022. [CrossRef]

33. Vogels, C.B.; Fros, J.J.; Göertz, G.P.; Pijlman, G.P.; Koenraadt, C.J. Vector competence of northern European Culex pipiens biotypes and hybrids for West Nile virus is differentially affected by temperature. Parasit Vectors 2016, 9, 393. [CrossRef] [PubMed]

34. Turell, M.J.; Rossi, C.A.; Bailey, C.L. Effect of extrinsic incubation temperature on the ability of Aedes taeniorhynchus and Culex pipiens to transmit Rift Valley fever virus. Am. J. Trop. Med. Hyg. 1985, 34, 1211-1218. [CrossRef] [PubMed]

35. Turell, M. Effect of environmental temperature on the vector competence of Aedes fowleri for Rift Valley fever virus. Res. Virol. 1989, 140, 147-154. [CrossRef]

36. Turell, M.J. Effect of environmental temperature on the vector competence of Aedes taeniorhynchus for Rift Valley fever and Venezuelan equine encephalitis viruses. Am. J. Trop. Med. Hyg. 1993, 49, 672-676. [CrossRef]

37. Kilpatrick, A.M.; Meola, M.A.; Moudy, R.M.; Kramer, L.D. Temperature, viral genetics, and the transmission of West Nile virus by Culex pipiens mosquitoes. PLoS Pathog. 2008, 4, e1000092. [CrossRef] [PubMed]

38. Anderson, S.L.; Richards, S.L.; Tabachnick, W.J.; Smartt, C.T. Effects of West Nile virus dose and extrinsic incubation temperature on temporal progression of vector competence in Culex pipiens quinquefasciatus. J. Am. Mosq. Control Assoc. 2010, 26, 103. [CrossRef]

39. Richards, S.L.; Mores, C.N.; Lord, C.C.; Tabachnick, W.J. Impact of extrinsic incubation temperature and virus exposure on vector competence of Culex pipiens quinquefasciatus Say (Diptera: Culicidae) for West Nile virus. Vector Borne Zoonotic Dis. 2007, 7, 629-636. [CrossRef]

40. Hurlbut, H.S. The effect of environmental temperature upon the transmission of St. Louis Encephalitis virus by Culex pipiens quinquefasciatus. J. Med. Entomol. 1973, 10, 1-12. [CrossRef]

41. Cornel, A.J.; Jupp, P.G.; Blackburn, N.K. Environmental temperature on the vector competence of Culex univittatus (Diptera: Culicidae) for West Nile virus. J. Med. Entomol. 1993, 30, 449-456. [CrossRef]

42. Takahashi, M. The effects of environmental and physiological conditions of Culex tritaeniorhynchus on the pattern of transmission of Japanese encephalitis virus. J. Med. Entomol. 1976, 13, 275-284. [CrossRef] 
43. Dohm, D.J.; O'Guinn, M.L.; Turell, M.J. Effect of environmental temperature on the ability of Culex pipiens (Diptera: Culicidae) to transmit West Nile virus. J. Med. Entomol. 2002, 39, 221-225. [CrossRef]

44. Reisen, W.K.; Fang, Y.; Martinez, V.M. Effects of Temperature on the Transmission of West Nile Virus by Culex tarsalis (Diptera: Culicidae). J. Med. Entomol. 2006, 43, 309-317. [CrossRef]

45. Kay, B.; Jennings, C. Enhancement or modulation of the vector competence of Ochlerotatus vigilax (Diptera: Culicidae) for Ross River virus by temperature. J. Med. Entomol. 2002, 39, 99-105. [CrossRef]

46. Kramer, L.D.; Hardy, J.L.; Presser, S.B. Effect of temperature of extrinsic incubation on the vector competence of Culex tarsalis for western equine encephalomyelitis virus. Am. J. Trop. Med. Hyg. 1983, 32, 1130-1139. [CrossRef] [PubMed]

47. Chamberlain, R.; Sudia, W.D. The effects of temperature upon the extrinsic incubation of eastern equine encephalitis in mosquitoes. Am. J. Trop. Med. Hyg. 1955, 62, 295-305.

48. Danforth, M.E.; Reisen, W.K.; Barker, C.M. The impact of cycling temperature on the transmission of West Nile virus. J. Med. Entomol. 2016, 53, 681-686. [CrossRef]

49. Brubaker, J.F.; Turell, M.J. Effect of environmental temperature on the susceptibility of Culex pipiens (Diptera: Culicidae) to Rift Valley fever virus. J. Med. Entomol. 1998, 35, 918-921. [CrossRef] [PubMed]

50. Ciota, A.T.; Styer, L.M.; Meola, M.A.; Kramer, L.D. The costs of infection and resistance as determinants of West Nile virus susceptibility in Culex mosquitoes. BMC Ecol. 2011, 11, 23. [CrossRef] [PubMed]

51. Kramer, L.D.; Hardy, J.L.; Presser, S.B.; Houk, E.J. Dissemination barriers for western equine encephalomyelitis virus in Culex tarsalis infected after ingestion of low viral doses. Am. J. Trop. Med. Hyg. 1981, 30, 190-197. [CrossRef]

52. Alto, B.W.; Wiggins, K.; Eastmond, B.; Ortiz, S.; Zirbel, K.; Lounibos, L.P. Diurnal temperature range and chikungunya virus infection in invasive mosquito vectors. J. Med. Entomol. 2018, 55, 217-224. [CrossRef]

53. Ciota, A.T.; Chin, P.A.; Ehrbar, D.J.; Micieli, M.V.; Fonseca, D.M.; Kramer, L.D. Differential effects of temperature and mosquito genetics determine transmissibility of arboviruses by Aedes aegypti in Argentina. Am. J. Trop. Med. Hyg. 2018, 99, 417-424. [CrossRef]

54. Tesla, B.; Demakovsky, L.R.; Mordecai, E.A.; Ryan, S.J.; Bonds, M.H.; Ngonghala, C.N.; Brindley, M.A.; Murdock, C.C. Temperature drives Zika virus transmission: evidence from empirical and mathematical models. Proc. Biol. Sci. 2018, 285, 20180795. [CrossRef]

55. Gloria-Soria, A.; Armstrong, P.; Powell, J.; Turner, P. Infection rate of Aedes aegypti mosquitoes with dengue virus depends on the interaction between temperature and mosquito genotype. Proc. Biol. Sci. 2017, 284, 20171506. [CrossRef]

56. Zouache, K.; Fontaine, A.; Vega-Rua, A.; Mousson, L.; Thiberge, J.-M.; Lourenco-De-Oliveira, R.; Caro, V.; Lambrechts, L.; Failloux, A.-B. Three-way interactions between mosquito population, viral strain and temperature underlying chikungunya virus transmission potential. Proc. Biol. Sci. 2014, 281, 20141078. [CrossRef]

57. Lambrechts, L.; Paaijmans, K.P.; Fansiri, T.; Carrington, L.B.; Kramer, L.D.; Thomas, M.B.; Scott, T.W. Impact of daily temperature fluctuations on dengue virus transmission by Aedes aegypti. Proc. Natl. Acad. Sci. USA 2011, 108, 7460-7465. [CrossRef]

58. Lambrechts, L.; Chevillon, C.; Albright, R.G.; Thaisomboonsuk, B.; Richardson, J.H.; Jarman, R.G.; Scott, T.W. Genetic specificity and potential for local adaptation between dengue viruses and mosquito vectors. BMC Evol. Biol. 2009, 9, 160. [CrossRef]

59. Carrington, L.B.; Seifert, S.N.; Armijos, M.V.; Lambrechts, L.; Scott, T.W. Reduction of Aedes aegypti vector competence for dengue virus under large temperature fluctuations. Am. J. Trop. Med. Hyg. 2013, 88, 689-697. [CrossRef]

60. Westbrook, C.J.; Reiskind, M.H.; Pesko, K.N.; Greene, K.E.; Lounibos, L.P. Larval environmental temperature and the susceptibility of Aedes albopictus Skuse (Diptera: Culicidae) to Chikungunya virus. Vector Borne Zoonotic Dis. 2010, 10, 241-247. [CrossRef]

61. Kay, B.H.; Fanning, I.D.; Mottram, P. Rearing temperature influences flavivirus vector competence of mosquitoes. Med. Vet. Entomol. 1989, 3, 415-422. [CrossRef]

62. Dodson, B.L.; Kramer, L.D.; Rasgon, J.L. Effects of larval rearing temperature on immature development and West Nile virus vector competence of Culex tarsalis. Parasit Vectors 2012, 5, 199. [CrossRef]

63. Muturi, E.J.; Alto, B.W. Larval environmental temperature and insecticide exposure alter Aedes aegypti competence for arboviruses. Vector Borne Zoonotic Dis. 2011, 11, 1157-1163. [CrossRef] [PubMed] 
64. Muturi, E.J.; Blackshear, M., Jr.; Montgomery, A. Temperature and density-dependent effects of larval environment on Aedes aegypti competence for an alphavirus. J. Vector Ecol. 2012, 37, 154-161. [CrossRef] [PubMed]

65. Muturi, E.J.; Kim, C.; Alto, B.W.; Berenbaum, M.R.; Schuler, M.A. Larval environmental stress alters Aedes aegypti competence for Sindbis virus. Trop. Med. Int. Health 2011, 16, 955-964. [CrossRef] [PubMed]

66. Ciota, A.T.; Matacchiero, A.C.; Kilpatrick, A.M.; Kramer, L.D. The effect of temperature on life history traits of Culex mosquitoes. J. Med. Entomol. 2014, 51, 55-62. [CrossRef]

67. Reisen, W.K. Effect of temperature on Culex tarsalis (Diptera: Culicidae) from the Coachella and San Joaquin valleys of California. J. Med. Entomol. 1995, 32, 636-645. [CrossRef]

68. Shelton, R.M. The effect of temperatures on development of eight mosquito species. Mosq. News 1973, 33, 1-12.

69. Paulson, S.; Hawley, W. Effect of body size on the vector competence of field and laboratory populations of Aedes triseriatus for La Crosse virus. J. Am. Mosq. Control Assoc. 1991, 7, 170-175.

70. Muturi, E.J.; Nyakeriga, A.; Blackshear, M. Temperature-mediated differential expression of immune and stress-related genes in Aedes aegypti larvae. J. Am. Mosq. Control Assoc. 2012, 28, 79-83. [CrossRef]

71. Adelman, Z.N.; Anderson, M.A.; Wiley, M.R.; Murreddu, M.G.; Samuel, G.H.; Morazzani, E.M.; Myles, K.M. Cooler temperatures destabilize RNA interference and increase susceptibility of disease vector mosquitoes to viral infection. PLoS Negl. Trop. Dis. 2013, 7, e2239. [CrossRef]

72. Spanoudis, C.G.; Andreadis, S.S.; Tsaknis, N.K.; Petrou, A.P.; Gkeka, C.D.; Savopoulou-Soultani, M. Effect of Temperature on Biological Parameters of the West Nile Virus Vector Culex pipiens form 'molestus' (Diptera: Culicidae) in Greece: Constant vs Fluctuating Temperatures. J. Med. Entomol. 2019, 56, 641-650. [CrossRef]

73. Gunay, F.; Alten, B.; Ozsoy, E.D. Estimating reaction norms for predictive population parameters, age specific mortality, and mean longevity in temperature-dependent cohorts of Culex quinquefasciatus Say (Diptera: Culicidae). J. Vector Ecol. 2010, 35, 354-362. [CrossRef] [PubMed]

74. Milby, M.; Meyer, R. The influence of constant versus fluctuating water temperatures on the preimaginal development of Culex tarsalis. J. Am. Mosq. Control Assoc. 1986, 2, 7-10. [PubMed]

75. Grech, M.G.; Sartor, P.D.; Almirón, W.R.; Ludueña-Almeida, F.F. Effect of temperature on life history traits during immature development of Aedes aegypti and Culex quinquefasciatus (Diptera: Culicidae) from Córdoba city, Argentina. Acta Trop. 2015, 146, 1-6. [CrossRef] [PubMed]

76. Alto, B.W.; Bettinardi, D. Temperature and dengue virus infection in mosquitoes: independent effects on the immature and adult stages. Am. J. Trop. Med. Hyg. 2013, 88, 497-505. [CrossRef] [PubMed]

77. Loetti, M.V.; Burroni, N.E.; Schweigmann, N.; De Garin, A. Effect of different thermal conditions on the pre-imaginal biology of Culex apicinus (Philippi, 1865) (Diptera: Culicidae). J. Vector Ecol. 2007, 32, 106-112. [CrossRef]

78. Loetti, V.; Schweigmann, N.; Burroni, N. Temperature effects on the immature development time of Culex eduardoi Casal \& García (Diptera: Culicidae). Neotrop. Entomol. 2011, 40, 138-142.

79. Mpho, M.; Callaghan, A.; Holloway, G. Temperature and genotypic effects on life history and fluctuating asymmetry in a field strain of Culex pipiens. Heredity 2002, 88, 307. [CrossRef]

80. Hagstrum, D.W.; Milliken, G.A. Modeling differences in insect developmental times between constant and fluctuating temperatures. Ann. Entomol. Soc. Am. 1991, 84, 369-379. [CrossRef]

81. Abouzied, E.M. Life table analysis of Culex pipiens under simulated weather conditions in Egypt. J. Am. Mosq. Control Assoc. 2017, 33, 16-24. [CrossRef]

82. Andreadis, S.S.; Dimotsiou, O.C.; Savopoulou-Soultani, M. Variation in adult longevity of Culex pipiens $f$. pipiens, vector of the West Nile Virus. Parasitol. Res. 2014, 113, 4315-4319. [CrossRef]

83. Alto, B.W.; Richards, S.L.; Anderson, S.L.; Lord, C.C. Survival of West Nile virus-challenged Southern house mosquitoes, Culex pipiens quinquefasciatus, in relation to environmental temperatures. J. Vector Ecol. 2014, 39, 123-133. [CrossRef] [PubMed]

84. Reuss, F.; Wieser, A.; Niamir, A.; Bálint, M.; Kuch, U.; Pfenninger, M.; Müller, R. Thermal experiments with the Asian bush mosquito (Aedes japonicus japonicus) (Diptera: Culicidae) and implications for its distribution in Germany. Parasit Vectors 2018, 11, 81. [CrossRef] [PubMed]

85. Westby, K.; Juliano, S. Simulated seasonal photoperiods and fluctuating temperatures have limited effects on blood feeding and life history in Aedes triseriatus (Diptera: Culicidae). J. Med. Entomol. 2015, 52, 896-906. [CrossRef] [PubMed] 
86. Reinhold, J.; Lazzari, C.; Lahondère, C. Effects of the environmental temperature on Aedes aegypti and Aedes albopictus mosquitoes: A Review. Insects 2018, 9, 158. [CrossRef]

87. Delatte, H.; Gimonneau, G.; Triboire, A.; Fontenille, D. Influence of temperature on immature development, survival, longevity, fecundity, and gonotrophic cycles of Aedes albopictus, vector of chikungunya and dengue in the Indian Ocean. J. Med. Entomol. 2009, 46, 33-41. [CrossRef]

88. Ruybal, J.E.; Kramer, L.D.; Kilpatrick, A.M. Geographic variation in the response of Culex pipiens life history traits to temperature. Parasit Vectors 2016, 9, 116. [CrossRef]

89. Eldridge, B.F. The effect of temperature and photoperiod on blood-feeding and ovarian development in mosquitoes of the Culex pipiens complex. Am. J. Trop. Med. Hyg. 1968, 17, 133-140. [CrossRef]

90. Parker, A.C.; Rozeboom, L.E. The effect of temperature and illumination on mating of Culex pipiens pipiens L. and C p fatigans Wied. Am. J. Trop. Med. Hyg. 1960, 9, 331-335. [CrossRef]

91. Kurokawa, K.; Kato, K.; Oda, T.; Uchida, K.; Eshita, Y.; Tahara, H.; Mine, M.; Ogawa, Y. Insemination rates of hybrids between Culex pipiens pipiens and Culex pipiens quinquefasciatus or Culex pipiens pallens at high temperature. J. Am. Mosq. Control Assoc. 2004, 20, 121-124.

92. Olejnícek, J.; Gelbic, I. Differences in response to temperature and density between two strains of the mosquito, Culex pipiens molestus Forskal. J. Vector Ecol. 2000, 25, 136-145.

93. Suman, D.; Tikar, S.; Mendki, M.; Sukumaran, D.; Agrawal, O.; Parashar, B.; Prakash, S. Variations in life tables of geographically isolated strains of the mosquito Culex quinquefasciatus. Med. Vet. Entomol. 2011, 25, 276-288. [CrossRef] [PubMed]

94. Scott, T.W.; Lorenz, L.H. Reduction of Culiseta melanura fitness by eastern equine encephalomyelitis virus. Am. J. Trop. Med. Hyg. 1998, 59, 341-346. [CrossRef] [PubMed]

95. Moncayo, A.C.; Edman, J.D.; Turell, M.J. Effect of eastern equine encephalomyelitis virus on the survival of Aedes albopictus, Anopheles quadrimaculatus, and Coquillettidia perturbans (Diptera: Culicidae). J. Med. Entomo. 2000, 37, 701-706. [CrossRef] [PubMed]

96. Ciota, A.T.; Ehrbar, D.J.; Matacchiero, A.C.; Van Slyke, G.A.; Kramer, L.D. The evolution of virulence of West Nile virus in a mosquito vector: implications for arbovirus adaptation and evolution. BMC Evol. Biol. 2013, 13, 71. [CrossRef] [PubMed]

97. Styer, L.M.; Meola, M.A.; Kramer, L.D. West Nile virus infection decreases fecundity of Culex tarsalis females. J. Med. Entomol. 2007, 44, 1074-1085. [CrossRef] [PubMed]

98. Jackson, B.T.; Brewster, C.C.; Paulson, S.L. La Crosse virus infection alters blood feeding behavior in Aedes triseriatus and Aedes albopictus (Diptera: Culicidae). J. Med. Entomol. 2012, 49, 1424-1429. [CrossRef]

99. Miller, R.H.; Masuoka, P.; Klein, T.A.; Kim, H.-C.; Somer, T.; Grieco, J. Ecological Niche Modeling to Estimate the Distribution of Japanese Encephalitis Virus in Asia. PLoS Negl. Trop. Dis. 2012, 6, e1678. [CrossRef]

100. Lebl, K.; Brugger, K.; Rubel, F. Predicting Culex pipiens/restuans population dynamics by interval lagged weather data. Parasit Vectors 2013, 6, 129. [CrossRef]

101. Root, T. Environmental factors associated with avian distributional boundaries. J. Biogeogr. 1988, 489-505. [CrossRef]

102. Khaliq, I.; Hof, C.; Prinzinger, R.; Böhning-Gaese, K.; Pfenninger, M. Global variation in thermal tolerances and vulnerability of endotherms to climate change. Proc. Biol. Sci. 2014, 281, 20141097. [CrossRef]

103. Darsie, R.; Ward, R. Identification and Geographical Distribution of the Mosquitoes of North. America, North. of Mexico, 2nd ed.; University Press of Florida: Gainesville, FL, USA, 2005.

104. Carpenter, S.J.; La Casse, W.J. Mosquitoes of North. America (North. of Mexico); Univ of California Press: Berkeley, CA, USA, 1955; ISBN 0-520-02638-1.

105. ECDPC Mosquito Maps. European Centre for Disease Prevention and Control. Available online: https: //ecdc.europa.eu/en/disease-vectors/surveillance-and-disease-data/mosquito-maps (accessed on 30 October 2019).

106. Foley, D.H.; Wilkerson, R.C.; Birney, I.; Harrison, S.; Christensen, J.; Rueda, L.M. MosquitoMap and the Mal-area calculator: new web tools to relate mosquito species distribution with vector borne disease. Int. J. Health Geogr. 2010, 9, 11. [CrossRef] [PubMed]

107. Kraemer, M.U.G.; Sinka, M.E.; Duda, K.A.; Mylne, A.Q.N.; Shearer, F.M.; Barker, C.M.; Moore, C.G.; Carvalho, R.G.; Coelho, G.E.; Van Bortel, W.; et al. The global distribution of the arbovirus vectors Aedes aegypti and Ae. albopictus. eLife 2015, 4, e08347. [CrossRef] [PubMed] 
108. Natureserve. NatureServe Web Service. Arlington, VA, USA. Available online: http://services.natureserve.org (accessed on 4 October 2019).

109. Natureserve. NatureServe Explorer: An Online Encyclopedia of Life (Web Application). Version 7.0. NatureServe, Arlington, VA, USA. Available online: http://explorer.natureserve.org (accessed on 4 October 2019).

110. GBIF. GBIF: The Global Biodiversity Information Facility: What is GBIF? 2019. Available online: https: //www.gbif.org/what-is-gbif (accessed on 4 October 2019).

111. Robbins, C.S.; Bystrak, D.; Geissler, P.H. The Breeding Bird Survey: Its First Fifteen Years, 1965-1979; Patuxent Wildlife Research Center: Laurel, MD, USA, 1986.

112. Sauer, J.R.; Niven, D.K.; Hines, J.E.; Ziolkowski, D.J., Jr.; Fallon, J.E.; Link, W.A. The North American Breeding Bird Survey, Results and Analyses 1966-2015; Version 2.07.2017; USGS Patuxent Wildlife Research Center: Laurel, MD, USA, 2017.

113. Sullivan, B.L.; Wood, C.L.; Iliff, M.J.; Bonney, R.E.; Fink, D.; Kelling, S. eBird: A citizen-based bird observation network in the biological sciences. Biol. Conserv. 2009, 142, 2282-2292. [CrossRef]

114. Dhileepan, K. Mosquito seasonality and arboviral disease incidence in Murray valley, southeast Australia. Med. Vet. Entomol. 1996, 10, 375-384. [CrossRef]

115. Chuang, T.-W.; Knepper, R.G.; Stanuszek, W.W.; Walker, E.D.; Wilson, M.L. Temporal and Spatial Patterns of West Nile Virus Transmission in Saginaw County, Michigan, 2003-2006. J. Med. Entomol. 2011, 48, 1047-1056. [CrossRef]

116. Russell, R. Mosquito-borne arboviruses in Australia: the current scene and implications of climate change for human health. Int. J. Parasitol. 1998, 28, 955-969. [CrossRef]

117. Morin, C.W.; Comrie, A.C. Regional and seasonal response of a West Nile virus vector to climate change. Proc. Natl. Acad. Sci. USA 2013, 110, 15620-15625. [CrossRef]

118. Paz, S.; Albersheim, I. Influence of warming tendency on Culex pipiens population abundance and on the probability of West Nile Fever outbreaks (Israeli case study: 2001-2005). EcoHealth 2008, 5, 40-48. [CrossRef]

119. Yoo, E.-H. Exploring space-time models for West Nile virus mosquito abundance data. Appl. Geogr. 2013, 45, 203-210. [CrossRef]

120. Yoo, E.-H.; Chen, D.; Diao, C.; Russell, C. The Effects of Weather and Environmental Factors on West Nile Virus Mosquito Abundance in Greater Toronto Area. Earth Interact. 2016, 20, 1-22. [CrossRef]

121. Rosa, R.; Marini, G.; Bolzoni, L.; Neteler, M.; Metz, M.; Delucchi, L.; Chadwick, E.A.; Balbo, L.; Mosca, A.; Giacobini, M.; et al. Early warning of West Nile virus mosquito vector: climate and land use models successfully explain phenology and abundance of Culex pipiens mosquitoes in north-western Italy. Parasit Vectors 2014, 7, 269. [CrossRef] [PubMed]

122. Burkett-Cadena, N.D.; Bingham, A.M.; Hunt, B.; Morse, G.; Unnasch, T.R. Ecology of Culiseta melanura and Other Mosquitoes (Diptera: Culicidae) from Walton County, FL, During Winter Period 2013-2014. J. Med. Entomol. 2015, 52, 1074-1082. [CrossRef] [PubMed]

123. Andreadis, T.G.; Shepard, J.J.; Thomas, M.C. Field observations on the overwintering ecology of Culiseta melanura in the Northeastern USA. J. Am. Mosq. Control Assoc. 2012, 28, 286-291. [CrossRef] [PubMed]

124. Hammami, P.; Tran, A.; Kemp, A.; Tshikae, P.; Kgori, P.; Chevalier, V.; Paweska, J.; Jori, F. Rift Valley fever vector diversity and impact of meteorological and environmental factors on Culex pipiens dynamics in the Okavango Delta, Botswana. Parasit Vectors 2016, 9, 434.

125. Biteye, B.; Fall, A.G.; Ciss, M.; Seck, M.T.; Apolloni, A.; Fall, M.; Tran, A.; Gimonneau, G. Ecological distribution and population dynamics of Rift Valley fever virus mosquito vectors (Diptera, Culicidae) in Senegal. Parasit Vectors 2018, 11, 27. [CrossRef]

126. Talla, C.; Diallo, D.; Dia, I.; Ba, Y.; Ndione, J.-A.; Morse, A.P.; Diop, A.; Diallo, M. Modelling hotspots of the two dominant Rift Valley fever vectors (Aedes vexans and Culex poicilipes) in Barkedji, Senegal. Parasit Vectors 2016, 9, 111. [CrossRef]

127. Talla, C.; Diallo, D.; Dia, I.; Ba, Y.; Ndione, J.-A.; Sall, A.A.; Morse, A.; Diop, A.; Diallo, M. Statistical Modeling of the Abundance of Vectors of West African Rift Valley Fever in Barkedji, Senegal. PLoS ONE 2014, 9, e114047. [CrossRef]

128. Conley, A.K.; Fuller, D.O.; Haddad, N.; Hassan, A.N.; Gad, A.M.; Beier, J.C. Modeling the distribution of the West Nile and Rift Valley Fever vector Culex pipiens in arid and semi-arid regions of the Middle East and North Africa. Parasit Vectors 2014, 7, 289. [CrossRef] 
129. Sallam, M.F.; Al Ahmed, A.M.; Abdel-Dayem, M.S.; Abdullah, M.A.R. Ecological Niche Modeling and Land Cover Risk Areas for Rift Valley Fever Vector, Culex tritaeniorhynchus Giles in Jazan, Saudi Arabia. PLoS ONE 2013, 8, e65786. [CrossRef]

130. Nance, J.; Fryxell, R.T.; Lenhart, S. Modeling a single season of Aedes albopictus populations based on host-seeking data in response to temperature and precipitation in eastern Tennessee. J. Vector Ecol. 2018, 43, 138-147. [CrossRef]

131. Ding, F.; Fu, J.; Jiang, D.; Hao, M.; Lin, G. Mapping the spatial distribution of Aedes aegypti and Aedes albopictus. Acta Trop. 2018, 178, 155-162. [CrossRef] [PubMed]

132. Alaniz, A.J.; Carvajal, M.A.; Bacigalupo, A.; Cattan, P.E. Global spatial assessment of Aedes aegypti and Culex quinquefasciatus: a scenario of Zika virus exposure. Epidemiol. Infect. 2019, 147, e52. [CrossRef] [PubMed]

133. Kamal, M.; Kenawy, M.A.; Rady, M.H.; Khaled, A.S.; Samy, A.M. Mapping the global potential distributions of two arboviral vectors Aedes aegypti and Ae. albopictus under changing climate. PLoS ONE 2018, 13, e0210122. [CrossRef] [PubMed]

134. Dickens, B.L.; Sun, H.; Jit, M.; Cook, A.R.; Carrasco, L.R. Determining environmental and anthropogenic factors which explain the global distribution of Aedes aegypti and Ae. albopictus. BMJ Glob. Health 2018, 3, e000801. [CrossRef] [PubMed]

135. Santos, J.; Meneses, B.M. An integrated approach for the assessment of the Aedes aegypti and Aedes albopictus global spatial distribution, and determination of the zones susceptible to the development of Zika virus. Acta Trop. 2017, 168, 80-90.

136. Messina, J.P.; Kraemer, M.U.G.; Brady, O.J.; Pigott, D.M.; Shearer, F.M.; Weiss, D.J.; Golding, N.; Ruktanonchar, C.W.; Gething, P.W.; Cohn, E.; et al. Mapping global environmental suitability for Zika virus. eLife 2016, 5, e15272. [CrossRef]

137. Campbell, L.P.; Luther, C.; Moo-Llanes, D.; Ramsey, J.M.; Danis-Lozano, R.; Peterson, A.T. Climate change influences on global distributions of dengue and chikungunya virus vectors. Philos. Trans. Royal Soc. B 2015, 370, 20140135. [CrossRef]

138. Capinha, C.; Rocha, J.; Sousa, C.A. Macroclimate Determines the Global Range Limit of Aedes aegypti. EcoHealth 2014, 11, 420-428. [CrossRef]

139. Khormi, H.M.; Kumar, L. Climate change and the potential global distribution of Aedes aegypti: spatial modelling using geographical information system and CLIMEX. Geospat Health 2014, 8, 405-415. [CrossRef]

140. Medley, K.A. Niche shifts during the global invasion of the Asian tiger mosquito, Aedes albopictus Skuse (Culicidae), revealed by reciprocal distribution models. Glob. Ecol. Biogeogr 2010, 19, 122-133. [CrossRef]

141. Samy, A.M.; Elaagip, A.H.; Kenawy, M.A.; Ayres, C.F.; Peterson, A.T.; Soliman, D.E. Climate change influences on the global potential distribution of the mosquito Culex quinquefasciatus, vector of West Nile virus and lymphatic filariasis. PLoS ONE 2016, 11, e0163863. [CrossRef] [PubMed]

142. Farajollahi, A.; Fonseca, D.M.; Kramer, L.D.; Kilpatrick, A.M. "Bird biting” mosquitoes and human disease: a review of the role of Culex pipiens complex mosquitoes in epidemiology. Infect. Genet. Evol. 2011, 11, 1577-1585. [CrossRef] [PubMed]

143. Hongoh, V.; Berrang-Ford, L.; Scott, M.E.; Lindsay, L.R. Expanding geographical distribution of the mosquito, Culex pipiens, in Canada under climate change. Appl. Geogr. 2012, 33, 53-62. [CrossRef]

144. Pearson, R.G.; Dawson, T.P. Predicting the impacts of climate change on the distribution of species: are bioclimate envelope models useful? Glob. Ecol. Biogeogr. 2003, 12, 361-371. [CrossRef]

145. Chaulk, A.C.; Carson, K.P.; Whitney, H.G.; Fonseca, D.M.; Chapman, T.W. The Arrival of the Northern House Mosquito Culex pipiens (Diptera: Culicidae) on Newfoundland's Avalon Peninsula. J. Med. Entomol. 2016, 53, 1364-1369. [CrossRef]

146. Morin, C.W.; Comrie, A.C. Modeled response of the West Nile virus vector Culex quinquefasciatus to changing climate using the dynamic mosquito simulation model. Int. J. Biometeorol. 2010, 54, 517-529. [CrossRef]

147. Carroll, C.; Lawler, J.J.; Roberts, D.R.; Hamann, A. Biotic and Climatic Velocity Identify Contrasting Areas of Vulnerability to Climate Change. PLoS ONE 2015, 10, e0140486. [CrossRef]

148. Young, S.G.; Tullis, J.A.; Cothren, J. A remote sensing and GIS-assisted landscape epidemiology approach to West Nile virus. Appl. Geogr. 2013, 45, 241-249. [CrossRef] 
149. Keyel, A.C.; Elison Timm, O.; Backenson, P.B.; Prussing, C.; Quinones, S.; McDonough, K.A.; Vuille, M.; Conn, J.E.; Armstrong, P.M.; Andreadis, T.G.; et al. Seasonal temperatures and hydrological conditions improve the prediction of West Nile virus infection rates in Culex mosquitoes and human case counts in New York and Connecticut. PLoS ONE 2019, 14, e0217854. [CrossRef]

150. Ruiz, M.O.; Chaves, L.F.; Hamer, G.L.; Sun, T.; Brown, W.M.; Walker, E.D.; Haramis, L.; Goldberg, T.L.; Kitron, U.D. Local impact of temperature and precipitation on West Nile virus infection in Culex species mosquitoes in northeast Illinois, USA. Parasit Vectors 2010, 3, 19. [CrossRef]

151. DeFelice, N.B.; Schneider, Z.D.; Little, E.; Barker, C.; Caillouet, K.A.; Campbell, S.R.; Damian, D.; Irwin, P.; Jones, H.M.P.; Townsend, J.; et al. Use of temperature to improve West Nile virus forecasts. PLoS Comput. Biol. 2018, 14, e1006407. [CrossRef] [PubMed]

152. Myer, M.H.; Campbell, S.R.; Johnston, J.M. Spatiotemporal modeling of ecological and sociological predictors of West Nile virus in Suffolk County, NY, mosquitoes. Ecosphere 2017, 8, e01854. [CrossRef] [PubMed]

153. Myer, M.H.; Johnston, J.M. Spatiotemporal Bayesian modeling of West Nile virus: Identifying risk of infection in mosquitoes with local-scale predictors. Sci. Total Environ. 2019, 650, 2818-2829. [CrossRef] [PubMed]

154. Little, E.; Campbell, S.R.; Shaman, J. Development and validation of a climate-based ensemble prediction model for West Nile Virus infection rates in Culex mosquitoes, Suffolk County, New York. Parasit Vectors 2016, 9, 443. [CrossRef] [PubMed]

155. Manore, C.A.; Davis, J.K.; Christofferson, R.C.; Wesson, D.M.; Hyman, J.M.; Mores, C.N. Towards an early warning system for forecasting human West Nile virus incidence. PLoS Curr. 2014, 6. [CrossRef]

156. Davis, J.K.; Vincent, G.P.; Hildreth, M.B.; Kightlinger, L.; Carlson, C.; Wimberly, M.C. Improving the prediction of arbovirus outbreaks: A comparison of climate-driven models for West Nile virus in an endemic region of the United States. Acta Trop. 2018, 185, 242-250.

157. Stratton, M.D.; Ehrlich, H.Y.; Mor, S.M.; Naumova, E.N. A comparative analysis of three vector-borne diseases across Australia using seasonal and meteorological models. Sci. Rep. 2017, 7, 40186. [CrossRef]

158. Soverow, J.E.; Wellenius, G.A.; Fisman, D.N.; Mittleman, M.A. Infectious disease in a warming world: how weather influenced West Nile virus in the United States (2001-2005). Environ. Health Perspect. 2009, 117, 1049. [CrossRef]

159. Trawinski, P.; Mackay, D. Meteorologically conditioned time-series predictions of West Nile virus vector mosquitoes. Vector Borne Zoonotic Dis. 2008, 8, 505-522. [CrossRef]

160. Poh, K.C.; Chaves, L.F.; Reyna-Nava, M.; Roberts, C.M.; Fredregill, C.; Bueno, R., Jr.; Debboun, M.; Hamer, G.L. The influence of weather and weather variability on mosquito abundance and infection with West Nile virus in Harris County, Texas, USA. Sci. Total Environ. 2019, 675, 260-272. [CrossRef]

161. Hartley, D.M.; Barker, C.M.; Le Menach, A.; Niu, T.; Gaff, H.D.; Reisen, W.K. Effects of Temperature on Emergence and Seasonality of West Nile Virus in California. Am. J. Trop. Med. Hyg. 2012, 86, 884-894. [CrossRef] [PubMed]

162. Kioutsioukis, I.; Stilianakis, N.I. Assessment of West nile virus transmission risk from a weather-dependent epidemiological model and a global sensitivity analysis framework. Acta Trop. 2019, 193, 129-141. [CrossRef] [PubMed]

163. Laperriere, V.; Brugger, K.; Rubel, F. Simulation of the seasonal cycles of bird, equine and human West Nile virus cases. Prev. Vet. Med. 2011, 98, 99-110. [CrossRef] [PubMed]

164. Lo Iacono, G.; Cunningham, A.A.; Bett, B.; Grace, D.; Redding, D.W.; Wood, J.L.N. Environmental limits of Rift Valley fever revealed using ecoepidemiological mechanistic models. Proc. Natl. Acad. Sci. USA 2018, 115, E7448-E7456. [CrossRef] [PubMed]

165. Mpeshe, S.C.; Luboobi, L.S.; Nkansah-Gyekye, Y. Modeling the Impact of Climate Change on the Dynamics of Rift Valley Fever. Comput. Math. Method M. 2014. [CrossRef]

166. Barker, C.M.; Niu, T.; Reisen, W.K.; Hartley, D.M. Data-Driven Modeling to Assess Receptivity for Rift Valley Fever Virus. PLoS Negl. Trop. Dis. 2013, 7, e2515. [CrossRef]

167. Shocket, M.S.; Ryan, S.J.; Mordecai, E.A. Temperature explains broad patterns of Ross River virus transmission. eLife 2018, 7, e37762. [CrossRef]

168. Barker, C.M. Models and Surveillance Systems to Detect and Predict West Nile Virus Outbreaks. J. Med. Entomol. 2019, 56, 1508-1515. [CrossRef]

169. Naish, S.; Mengersen, K.; Hu, W.; Tong, S. Forecasting the Future Risk of Barmah Forest Virus Disease under Climate Change Scenarios in Queensland, Australia. PLoS ONE 2013, 8, e62843. [CrossRef] 
170. Naish, S.; Mengersen, K.; Tong, S. Spatial analysis of risk factors for transmission of the Barmah Forest virus in Queensland, Australia. Geospat. Health 2013, 8, 289-299. [CrossRef]

171. Takeda, T.; Whitehouse, C.; Brewer, M.; Gettman, A.; Mather, T. Arbovirus surveillance in Rhode Island: Assessing potential ecologic and climatic correlates. J. Am. Mosq. Control Assoc. 2003, 19, 179-189. [PubMed]

172. Brummer-Korvenkontio, M.; Vapalahti, O.; Kuusisto, P.; Saikku, P.; Manni, T.; Koskela, P.; Nygren, T.; Brummer-Korvenkontio, H.; Vaheri, A. Epidemiology of Sindbis virus infections in Finland 1981-96: possible factors explaining a peculiar disease pattern. Epidemiol. Infect. 2002, 129, 335-345. [CrossRef] [PubMed]

173. Uejio, C.K.; Kemp, A.; Comrie, A.C. Climatic Controls on West Nile Virus and Sindbis Virus Transmission and Outbreaks in South Africa. Vector Borne Zoonotic Dis. 2012, 12, 117-125. [CrossRef] [PubMed]

174. Barker, C.; Reisen, W.; Kramer, V. California state mosquito-borne virus surveillance and response plan: A retrospective evaluation using conditional simulations. Am. J. Trop. Med. Hyg. 2003, 68, 508-518. [CrossRef] [PubMed]

175. Sellers, R.; Maarouf, A. Weather factors in the prediction of western equine encephalitis epidemics in Manitoba. Epidemiol. Infect. 1993, 111, 373-390. [CrossRef] [PubMed]

176. Barker, C.M.; Johnson, W.O.; Eldridge, B.F.; Park, B.K.; Melton, F.; Reisen, W.K. Temporal connections between Culex tarsalis abundance and transmission of Western Equine Encephalomyelitis Virus in California. Am. J. Trop. Med. Hyg. 2010, 82, 1185-1193. [CrossRef]

177. Unnasch, R.S.; Sprenger, T.; Katholi, C.R.; Cupp, E.W.; Hill, G.E.; Unnasch, T.R. A dynamic transmission model of eastern equine encephalitis virus. Ecol. Model 2006, 192, 425-440. [CrossRef]

178. Skaff, N.K.; Armstrong, P.M.; Andreadis, T.G.; Cheruvelil, K.S. Wetland characteristics linked to broad-scale patterns in Culiseta melanura abundance and eastern equine encephalitis virus infection. Parasit Vectors 2017, 10, 501. [CrossRef]

179. Hahn, M.B.; Monaghan, A.J.; Hayden, M.H.; Eisen, R.J.; Delorey, M.J.; Lindsey, N.P.; Nasci, R.S.; Fischer, M. Meteorological conditions associated with increased incidence of West Nile virus disease in the United States, 2004-2012. Am. J. Trop. Med. Hyg. 2015, 92, 1013-1022. [CrossRef]

180. Shaman, J.; Harding, K.; Campbell, S.R. Meteorological and hydrological influences on the spatial and temporal prevalence of West Nile virus in Culex mosquitoes, Suffolk County, New York. J. Med. Entomol. 2011, 48, 867-875. [CrossRef]

181. Liu, A.; Lee, V.; Galusha, D.; Slade, M.D.; Diuk-Wasser, M.; Andreadis, T.; Scotch, M.; Rabinowitz, P.M. Risk factors for human infection with West Nile Virus in Connecticut: A multi-year analysis. Int. J. Health Geogr. 2009, 8, 67. [CrossRef] [PubMed]

182. Walsh, M.G. The Role of Hydrogeography and Climate in the Landscape Epidemiology of West Nile Virus in New York State from 2000 to 2010. PLoS ONE 2012, 7, e30620. [CrossRef] [PubMed]

183. Sallam, M.; Michaels, S.; Riegel, C.; Pereira, R.; Zipperer, W.; Lockaby, B.; Koehler, P. Spatio-temporal distribution of vector-host contact (VHC) ratios and ecological niche modeling of the West Nile virus mosquito vector, Culex quinquefasciatus, in the City of New Orleans, LA, USA. Int. J. Environ. Res. Public Health 2017, 14, 892. [CrossRef] [PubMed]

184. Tran, A.; Sudre, B.; Paz, S.; Rossi, M.; Desbrosse, A.; Chevalier, V.; Semenza, J.C. Environmental predictors of West Nile fever risk in Europe. Int. J. Health Geogr. 2014, 13, 26. [CrossRef] [PubMed]

185. Paz, S. The West Nile Virus outbreak in Israel (2000) from a new perspective: The regional impact of climate change. Int. J. Environ. Health Res. 2006, 16, 1-13. [CrossRef]

186. Platonov, A.E.; Tolpin, V.A.; Gridneva, K.A.; Titkov, A.V.; Platonova, O.V.; Kolyasnikova, N.M.; Busani, L.; Rezza, G. The Incidence of West Nile Disease in Russia in Relation to Climatic and Environmental Factors. Int. J. Environ. Res. Public Health 2014, 11, 1211-1232. [CrossRef]

187. Platonov, A.E.; Fedorova, M.V.; Karan, L.S.; Shopenskaya, T.A.; Platonova, O.V.; Zhuravlev, V.I. Epidemiology of West Nile infection in Volgograd, Russia, in relation to climate change and mosquito (Diptera: Culicidae) bionomics. Parasitol. Res. 2008, 103, 45-53. [CrossRef]

188. Bakonyi, T.; Ferenczi, E.; Erdelyi, K.; Kutasi, O.; Csoergo, T.; Seidel, B.; Weissenboeck, H.; Brugger, K.; Ban, E.; Nowotny, N. Explosive spread of a neuroinvasive lineage 2 West Nile virus in Central Europe, 2008/2009. Vet. Microbiol. 2013, 165, 61-70. [CrossRef]

189. Marcantonio, M.; Rizzoli, A.; Metz, M.; Rosa, R.; Marini, G.; Chadwick, E.; Neteler, M. Identifying the Environmental Conditions Favouring West Nile Virus Outbreaks in Europe. PLoS ONE 2015, 10, e0121158. [CrossRef] 
190. Davis, J.K.; Vincent, G.; Hildreth, M.B.; Kightlinger, L.; Carlson, C.; Wimberly, M.C. Integrating Environmental monitoring and mosquito surveillance to predict vector-borne disease: prospective forecasts of a West Nile virus outbreak. PLoS Curr. 2017, 9. [CrossRef]

191. Gibbs, S.; Wimberly, M.; Madden, M.; Masour, J.; Yabsley, M.; Stallknecht, D. Factors affecting the geographic distribution of West Nile virus in Georgia, USA: 2002-2004. Vector Borne Zoonotic Dis. 2006, 6, 73-82. [CrossRef] [PubMed]

192. Chen, C.-C.; Epp, T.; Jenkins, E.; Waldner, C.; Curry, P.S.; Soos, C. Modeling Monthly Variation of Culex tarsalis (Diptera: Culicidae) Abundance and West Nile Virus Infection Rate in the Canadian Prairies. Int. J. Environ. Res. Public Health 2013, 10, 3033-3051. [CrossRef] [PubMed]

193. Epp, T.Y.; Waldner, C.L.; Berke, O. Predicting Geographical Human Risk of West Nile Virus-Saskatchewan, 2003 and 2007. Can. J. Public Health 2009, 100, 344-348. [CrossRef] [PubMed]

194. Bai, Y.; Xu, Z.; Zhang, J.; Mao, D.; Luo, C.; He, Y.; Liang, G.; Lu, B.; Bisesi, M.S.; Sun, Q.; et al. Regional Impact of Climate on Japanese Encephalitis in Areas Located near the Three Gorges Dam. PLoS ONE 2014, 9, e84326. [CrossRef]

195. Mogi, M. Relationship between number of human Japanese encephalitis cases and summer meteorological conditions in Nagasaki, Japan. Am. J. Trop. Med. Hyg. 1983, 32, 170-174. [CrossRef]

196. Bi, P.; Zhang, Y.; Parton, K.A. Weather variables and Japanese encephalitis in the metropolitan area of Jinan city, China. J. Infect. 2007, 55, 551-556. [CrossRef]

197. Lin, H.; Yang, L.; Liu, Q.; Wang, T.; Hossain, S.R.; Ho, S.C.; Tian, L. Time series analysis of Japanese encephalitis and weather in Linyi City, China. Int. J. Public Health 2012, 57, 289-296. [CrossRef]

198. Lin, C.-L.; Chang, H.-L.; Lin, C.-Y.; Chen, K.-T. Seasonal Patterns of Japanese Encephalitis and Associated Meteorological Factors in Taiwan. Int. J. Environ. Res. Public Health 2017, 14, 1317. [CrossRef]

199. Hsu, S.M.; Yen, A.M.F.; Chen, T.H.H. The impact of climate on Japanese encephalitis. Epidemiol. Infect. 2008, 136, 980-987. [CrossRef]

200. Reiter, P. Weather, vector biology, and arboviral recrudescence. In The Arboviruses: Epidemiology and Ecology; Monath, T., Ed.; CRC Press: Boca Raton, FL, USA, 1988; Volume 1, pp. 245-255.

201. Reisen, W.; Lothrop, H.; Chiles, R.; Cusack, R.; Green, E.; Fang, Y.; Kensington, M. Persistence and amplification of St. Louis encephalitis virus in the Coachella Valley of California, 2000-2001. J. Med. Entomol. 2002, 39, 793-805. [CrossRef]

202. Reisen, W.; Hardy, J.; Presser, S.; Milby, M.; Meyer, R.; Durso, S.; Wargo, M.; Gordon, E. Mosquito and arbovirus ecology in southeastern California, 1986-1990. J. Med. Entomol. 1992, 29, 512-524. [CrossRef] [PubMed]

203. Bi, P.; Tong, S.; Donald, K.; Parton, K.; Ni, J. Climate variability and transmission of Japanese encephalitis in Eastern China. Vector Borne Zoonotic Dis. 2003, 3, 111-115. [CrossRef] [PubMed]

204. Wang, L.; Hu, W.; Magalhaes, R.J.S.; Bi, P.; Ding, F.; Sun, H.; Li, S.; Yin, W.; Wei, L.; Liu, Q.; et al. The role of environmental factors in the spatial distribution of Japanese encephalitis in mainland China. Environ. Int. 2014, 73, 1-9. [CrossRef] [PubMed]

205. Prow, N. The changing epidemiology of Kunjin virus in Australia. Int. J. Environ. Res. Public Health 2013, 10, 6255-6272. [CrossRef] [PubMed]

206. Jansen, C.; Ritchie, S.; van den Hurk, A. The role of Australian mosquito species in the transmission of endemic and exotic West Nile virus strains. Int. J. Environ. Res. Public Health 2013, 10, 3735-3752. [CrossRef] [PubMed]

207. Hoover, K.C.; Barker, C.M. West Nile virus, climate change, and circumpolar vulnerability. Wiley Interdiscip. Rev. Clim. Chang. 2016, 7, 283-300. [CrossRef]

208. Harrigan, R.J.; Thomassen, H.A.; Buermann, W.; Smith, T.B. A continental risk assessment of West Nile virus under climate change. Glob. Chang. Biol. 2014, 20, 2417-2425. [CrossRef]

209. Semenza, J.C.; Tran, A.; Espinosa, L.; Sudre, B.; Domanovic, D.; Paz, S. Climate change projections of West Nile virus infections in Europe: implications for blood safety practices. Environ. Health 2016, 15, S28. [CrossRef]

210. Fros, J.J.; Geertsema, C.; Vogels, C.B.; Roosjen, P.P.; Failloux, A.-B.; Vlak, J.M.; Koenraadt, C.J.; Takken, W.; Pijlman, G.P. West Nile Virus: High Transmission Rate in North-Western European Mosquitoes Indicates Its Epidemic Potential and Warrants Increased Surveillance. PLoS Negl. Trop. Dis. 2015, 9, e0003956. [CrossRef] 
211. Chen, C.C.; Jenkins, E.; Epp, T.; Waldner, C.; Curry, P.S.; Soos, C. Climate change and West Nile virus in a highly endemic region of North America. Int. J. Environ. Res. Public Health 2013, 10, 3052-3071. [CrossRef]

212. Paz, S.; Semenza, J.C. Environmental drivers of West Nile fever epidemiology in Europe and Western Asia-A review. Int. J. Environ. Res. Public Health 2013, 10, 3543-3562. [CrossRef] [PubMed]

213. Reeves, W.C.; Hardy, J.L.; Reisen, W.K.; Milby, M.M. Potential effect of global warming on mosquito-borne arboviruses. J. Med. Entomol. 1994, 31, 323-332. [CrossRef] [PubMed]

214. Hess, A.; Cherubin, C.; LaMotte, L. Relation of temperature to activity of western and St. Louis encephalitis viruses. Am. J. Trop. Med. Hyg. 1963, 12, 657-667. [CrossRef]

215. Borah, J.; Dutta, P.; Khan, S.A.; Mahanta, J. Association of Weather and Anthropogenic Factors for Transmission of Japanese Encephalitis in an Endemic Area of India. EcoHealth 2013, 10, 129-136. [CrossRef]

216. Murty, U.S.; Rao, M.S.; Arunachalam, N. The effects of climatic factors on the distribution and abundance of Japanese encephalitis vectors in Kurnool district of Andhra Pradesh, India. J. Vector Dis. 2010, 47, $26-32$.

217. Upadhyayula, S.M.; Mutheneni, S.R.; Nayanoori, H.K.; Natarajan, A.; Goswami, P. Impact of weather variables on mosquitoes infected with Japanese encephalitis virus in Kurnool district, Andhra Pradesh. Asian Pac. J. Trop. Med. 2012, 5, 337-341. [CrossRef]

218. Impoinvil, D.E.; Ooi, M.H.; Diggle, P.J.; Caminade, C.; Cardosa, M.J.; Morse, A.P.; Baylis, M.; Solomon, T. The Effect of Vaccination Coverage and Climate on Japanese Encephalitis in Sarawak, Malaysia. PLoS Negl. Trop. Dis. 2013, 7, e2334. [CrossRef]

219. Hardy, J.L.; Rosen, L.; Reeves, W.C.; Scrivani, R.P.; Presser, S.B. Experimental transovarial transmission of St. Louis encephalitis virus by Culex and Aedes mosquitoes. Am. J. Trop. Med. Hyg. 1984, 33, 166-175. [CrossRef]

220. Heinrich, N.; Saathoff, E.; Weller, N.; Clowes, P.; Kroidl, I.; Ntinginya, E.; Machibya, H.; Maboko, L.; Loescher, T.; Dobler, G.; et al. High Seroprevalence of Rift Valley Fever and Evidence for Endemic Circulation in Mbeya Region, Tanzania, in a Cross-Sectional Study. PLoS Negl. Trop. Dis. 2012, 6, e1557. [CrossRef]

221. Anyamba, A.; Small, J.L.; Britch, S.C.; Tucker, C.J.; Pak, E.W.; Reynolds, C.A.; Crutchfield, J.; Linthicum, K.J. Recent Weather Extremes and Impacts on Agricultural Production and Vector-Borne Disease Outbreak Patterns. PLoS ONE 2014, 9, e92538. [CrossRef]

222. Clements, A.C.A.; Pfeiffer, D.U.; Martin, V.; Pittiglio, C.; Best, N.; Thiongane, Y. Spatial risk assessment of Rift Valley fever in Senegal. Vector Borne Zoonotic Dis. 2007, 7, 203-216. [CrossRef] [PubMed]

223. Martin, V.; Chevalier, V.; Ceccato, P.; Anyamba, A.; De Simone, L.; Lubroth, J.; de la Rocque, S.; Domenech, J. The impact of climate change on the epidemiology and control of Rift Valley fever. Rev. Sci Tech. OIE 2008, 27, 413-426. [CrossRef]

224. Metras, R.; Fournie, G.; Dommergues, L.; Camacho, A.; Cavalerie, L.; Merot, P.; Keeling, M.J.; Cetre-Sossah, C.; Cardinale, E.; Edmunds, W.J. Drivers for Rift Valley fever emergence in Mayotte: A Bayesian modelling approach. PLoS Negl. Trop. Dis. 2017, 11, e0005767. [CrossRef] [PubMed]

225. Gatton, M.; Kay, B.; Ryan, P. Environmental predictors of Ross River virus disease outbreaks in Queensland, Australia. Am. J. Trop. Med. Hyg. 2005, 72, 792-799. [CrossRef]

226. Impoinvil, D.E.; Solomon, T.; Schluter, W.W.; Rayamajhi, A.; Bichha, R.P.; Shakya, G.; Caminade, C.; Baylis, M. The Spatial Heterogeneity between Japanese Encephalitis Incidence Distribution and Environmental Variables in Nepal. PLoS ONE 2011, 6, e22192. [CrossRef]

227. Cotar, A.I.; Falcuta, E.; Prioteasa, L.F.; Dinu, S.; Ceianu, C.S.; Paz, S. Transmission Dynamics of the West Nile Virus in Mosquito Vector Populations under the Influence of Weather Factors in the Danube Delta, Romania. EcoHealth 2016, 13, 796-807. [CrossRef]

228. Shaman, J.; Day, J.F.; Stieglitz, M. Drought-induced amplification and epidemic transmission of West Nile virus in southern Florida. J. Med. Entomol. 2005, 42, 134-141. [CrossRef]

229. Paull, S.H.; Horton, D.E.; Ashfaq, M.; Rastogi, D.; Kramer, L.D.; Diffenbaugh, N.S.; Kilpatrick, A.M. Drought and immunity determine the intensity of West Nile virus epidemics and climate change impacts. Proc. $R$. Soc. B 2017, 284, 20162078. [CrossRef]

230. Johnson, B.J.; Sukhdeo, M.V.K. Drought-Induced Amplification of Local and Regional West Nile Virus Infection Rates in New Jersey. J. Med. Entomol. 2013, 50, 195-204. [CrossRef]

231. Day, J.F.; Shaman, J. Using hydrologic conditions to forecast the risk of focal and epidemic arboviral transmission in peninsular Florida. J. Med. Entomol. 2008, 45, 458-465. [CrossRef]

232. Shaman, J.; Day, J.F.; Stieglitz, M. Drought-induced amplification of Saint Louis encephalitis virus, Florida. Emerg Infect. Dis. 2002, 8, 575-580. [CrossRef] [PubMed] 
233. Reisen, W.; Meyer, R.; Milby, M.; Presser, S.; Emmons, R.; Hardy, J.; Reeves, W. Ecological observations on the 1989 outbreak of St-Louis Encephalitis-virus in the southern San Joaquin Valley of California. J. Med. Entomol. 1992, 29, 472-482. [CrossRef]

234. Day, J.F.; Shaman, J. Severe Winter Freezes Enhance St. Louis Encephalitis Virus Amplification and Epidemic Transmission in Peninsular Florida. J. Med. Entomol. 2009, 46, 1498-1506. [CrossRef] [PubMed]

235. Day, J.F.; Stark, L.M. Avian serology in a St. Louis encephalitis epicenter before, during, and after a widespread epidemic in south Florida, USA. J. Med. Entomol. 1999, 36, 614-624. [CrossRef] [PubMed]

236. Jourdain, E.; Olsen, B.; Lundkvist, A.; Hubálek, Z.; Šikutová, S.; Waldenström, J.; Karlsson, M.; Wahlström, M.; Jozan, M.; Falk, K.I. Surveillance for West Nile virus in wild birds from northern Europe. Vector Borne Zoonotic Dis. 2011, 11, 77-79. [CrossRef]

237. Li, Y.-X.; Li, M.-H.; Fu, S.-H.; Chen, W.-X.; Liu, Q.-Y.; Zhang, H.-L.; Da, W.; Hu, S.-L.; Mu, S.D.L.; Bai, J.; et al. Japanese encephalitis, Tibet, China. Emerg Infect. Dis. 2011, 17, 934-936. [CrossRef]

238. Ho, S.H.; Speldewinde, P.; Cook, A. A Bayesian Belief Network for Murray Valley encephalitis virus risk assessment in Western Australia. Int. J. Health Geogr. 2016, 15, 6. [CrossRef]

239. Reisen, W.; Kramer, L.; Chiles, R.; Wolfe, T.; Green, E. Simulated overwintering of Encephalitis viruses in diapausing female Culex tarsalis (Diptera: Culicidae). J. Med. Entomol. 2002, 39, 226-233. [CrossRef]

240. Montecino-Latorre, D.; Barker, C.M. Overwintering of West Nile virus in a bird community with a communal crow roost. Sci. Rep. 2018, 8, 6088. [CrossRef]

241. Reisen, W.K.; Wheeler, S.S. Overwintering of West Nile Virus in the United States. J. Med. Entomol. 2019, 56, 1498-1507. [CrossRef]

242. Andreadis, T.G.; Anderson, J.F.; Vossbrinck, C.R.; Main, A.J. Epidemiology of West Nile virus in Connecticut: a five-year analysis of mosquito data 1999-2003. Vector Borne Zoonotic Dis. 2004, 4, 360-378. [CrossRef] [PubMed]

243. Paz, S.; Malkinson, D.; Green, M.S.; Tsioni, G.; Papa, A.; Danis, K.; Sirbu, A.; Ceianu, C.; Katalin, K.; Ferenczi, E.; et al. Permissive Summer Temperatures of the 2010 European West Nile Fever Upsurge. PLoS ONE 2013, 8, e56398. [CrossRef] [PubMed]

244. Ukawuba, I.; Shaman, J. Association of spring-summer hydrology and meteorology with human West Nile virus infection in West Texas, USA, 2002-2016. Parasit Vectors 2018, 11, 224. [CrossRef] [PubMed]

245. Conte, A.; Candeloro, L.; Ippoliti, C.; Monaco, F.; De Massis, F.; Bruno, R.; Di Sabatino, D.; Luisa Danzetta, M.; Benjelloun, A.; Belkadi, B.; et al. Spatio-Temporal Identification of Areas Suitable for West Nile Disease in the Mediterranean Basin and Central Europe. PLoS ONE 2015, 10, e0146024. [CrossRef] [PubMed]

246. Kilpatrick, A.M.; Kramer, L.D.; Jones, M.J.; Marra, P.P.; Daszak, P. West Nile virus epidemics in North America are driven by shifts in mosquito feeding behavior. PLoS Biol. 2006, 4, e82. [CrossRef]

247. Naish, S.; Hu, W.; Nicholls, N.; Mackenzie, J.; McMichael, A.; Dale, P.; Tong, S. Weather variability, tides, and Barmah Forest virus disease in the Gladstone region, Australia. Environ. Health Perspect. 2006, 114, 678-683. [CrossRef]

248. Naish, S.; Hu, W.; Nicholls, N.; Mackenzie, J.S.; Dale, P.; McMichael, A.J.; Tong, S. Socio-environmental predictors of Barmah forest virus transmission in coastal areas, Queensland, Australia. Trop. Med. Int. Health 2009, 14, 247-256. [CrossRef]

249. Simpson, E.H. The interpretation of interaction in contingency tables. J. Royal Stat. Soc. B 1951, 13, $238-241$. [CrossRef]

250. Blyth, C.R. On Simpson's Paradox and the Sure-Thing Principle. J. Am. Stat. Assoc. 1972, 67, $364-366$. [CrossRef]

251. Woodruff, R.E.; Guest, C.S.; Gainer, M.G.; Becker, N.; Lindsay, M. Early warning of ross River Virus epidemics-Combining surveillance data on climate and mosquitoes. Epidemiology 2006, 17, 569-575. [CrossRef]

252. Woodruff, R.E.; Guest, C.S.; Garner, M.G.; Becker, N.; Lindesay, J.; Carvan, T.; Ebi, K. Predicting Ross River virus epidemics from regional weather data. Epidemiology 2002, 384-393. [CrossRef] [PubMed]

253. McIver, L.; Xiao, J.; Lindsay, M.D.; Rowe, T.; Yun, G. A climate-based early warning system to predict outbreaks of Ross River virus disease in the Broome region of Western Australia. Aust. N. Z. J. Public Health 2010, 34, 89-90. [CrossRef] [PubMed] 
254. Williams, C.R.; Fricker, S.R.; Kokkinn, M.J. Environmental and entomological factors determining Ross River virus activity in the River Murray Valley of South Australia. Aust. N. Z. J. Public Health 2009, 33, 284-288. [CrossRef] [PubMed]

255. Bi, P.; Hiller, J.E.; Cameron, A.S.; Zhang, Y.; Givney, R. Climate variability and Ross River virus infections in Riverland, South Australia, 1992-2004. Epidemiol. Infect. 2009, 137, 1486-1493. [CrossRef] [PubMed]

256. Werner, A.K.; Goater, S.; Carver, S.; Robertson, G.; Allen, G.R.; Weinstein, P. Environmental drivers of Ross River virus in southeastern Tasmania, Australia: towards strengthening public health interventions. Epidemiol. Infect. 2012, 140, 359-371. [CrossRef] [PubMed]

257. Koolhof, I.S.; Bettiol, S.; Carver, S. Fine-temporal forecasting of outbreak probability and severity: Ross River virus in Western Australia. Epidemiol. Infect. 2017, 145, 2949-2960. [CrossRef]

258. Tong, S.; Bi, P.; Donald, K.; McMichael, A. Climate variability and Ross River virus transmission. J. Epidemiol. Community Health 2002, 56, 617-621. [CrossRef]

259. Hu, W.; Clements, A.; Williams, G.; Tong, S.; Mengersen, K. Bayesian Spatiotemporal Analysis of Socio-Ecologic Drivers of Ross River Virus Transmission in Queensland, Australia. Am. J. Trop. Med. Hyg. 2010, 83, 722-728. [CrossRef]

260. Hu, W.; Nicholls, N.; Lindsay, M.; Dale, P.; McMichael, A.; Mackenzie, J.; Tong, S. Development of a predictive model for Ross River virus disease in Brisbane, Australia. Am. J. Trop. Med. Hyg. 2004, 71, 129-137. [CrossRef]

261. Kelly-Hope, L.; Purdie, D.; Kay, B. Differences in climatic factors between Ross River virus disease outbreak and nonoutbreak years. J. Med. Entomol. 2004, 41, 1116-1122. [CrossRef]

262. Tong, S.; Hu, W. Different responses of Ross River virus to climate variability between coastline and inland cities in Queensland, Australia. Occup. Environ. Med. 2002, 59, 739-744. [CrossRef] [PubMed]

263. Tong, S.; Hu, W.; McMichael, A. Climate variability and Ross River virus transmission in Townsville region, Australia, 1985-1996. Trop. Med. Int. Health 2004, 9, 298-304. [CrossRef] [PubMed]

264. Linthicum, K.; Anyamba, A.; Tucker, C.; Kelley, P.; Myers, M.; Peters, C. Climate and satellite indicators to forecast Rift Valley fever epidemics in Kenya. Science 1999, 285, 397-400. [CrossRef] [PubMed]

265. Anyamba, A.; Chretien, J.-P.; Small, J.; Tucker, C.J.; Formenty, P.B.; Richardson, J.H.; Britch, S.C.; Schnabelf, D.C.; Erickson, R.L.; Linthicum, K.J. Prediction of a Rift Valley fever outbreak. Proc. Natl. Acad. Sci. USA 2009, 106, 955-959. [CrossRef]

266. Gikungu, D.; Wakhungu, J.; Siamba, D.; Neyole, E.; Muita, R.; Bett, B. Dynamic risk model for Rift Valley fever outbreaks in Kenya based on climate and disease outbreak data. Geospat Health 2016, 11, 95-103. [CrossRef]

267. Mweya, C.N.; Holst, N.; Mboera, L.E.G.; Kimera, S.I. Simulation Modelling of Population Dynamics of Mosquito Vectors for Rift Valley Fever Virus in a Disease Epidemic Setting. PLoS ONE 2014, 9, e108430. [CrossRef]

268. Sindato, C.; Stevens, K.B.; Karimuribo, E.D.; Mboera, L.E.G.; Paweska, J.T.; Pfeiffer, D.U. Spatial Heterogeneity of Habitat Suitability for Rift Valley Fever Occurrence in Tanzania: An Ecological Niche Modelling Approach. PLOS Negl. Trop. Dis. 2016, 10, e0005002. [CrossRef]

269. Metras, R.; Jewell, C.; Porphyre, T.; Thompson, P.N.; Pfeiffer, D.U.; Collins, L.M.; White, R.G. Risk factors associated with Rift Valley fever epidemics in South Africa in 2008-11. Sci. Rep. 2015, 5, 9492. [CrossRef]

270. Nicholas, D.E.; Delamater, P.L.; Waters, N.M.; Jacobsen, K.H. Geographically weighted discriminant analysis of environmental conditions associated with Rift Valley fever outbreaks in South Africa. Spat. Spatio-temporal Epidemiol. 2016, 17, 75-83. [CrossRef]

271. Arsevska, E.; Hellal, J.; Mejri, S.; Hammami, S.; Marianneau, P.; Calavas, D.; Henaux, V. Identifying Areas Suitable for the Occurrence of Rift Valley Fever in North Africa: Implications for Surveillance. Transbound. Emerg. Dis. 2016, 63, 658-674. [CrossRef]

272. Sanchez-Vizcaino, F.; Martinez-Lopez, B.; Manuel Sanchez-Vizcaino, J. Identification of suitable areas for the occurrence of Rift Valley fever outbreaks in Spain using a multiple criteria decision framework. Vet. Microbiol. 2013, 165, 71-78. [CrossRef] [PubMed]

273. Konrad, S.K.; Miller, S.N. A temperature-limited assessment of the risk of Rift Valley fever transmission and establishment in the continental United States of America. Geospat Health 2012, 6, 161-170. [CrossRef] [PubMed] 
274. Newman, A.J.; Clark, M.P.; Craig, J.; Nijssen, B.; Wood, A.; Gutmann, E.; Mizukami, N.; Brekke, L.; Arnold, J.R. Gridded ensemble precipitation and temperature estimates for the contiguous United States. J. Hydrometeorol. 2015, 16, 2481-2500. [CrossRef]

275. PRISM Climate Group Parameter-elevation Regression on Independent Slopes Model. Oregon State University, 2019. Available online: http://prism.oregonstate.edu (accessed on 30 October 2019).

276. Haider, N.; Kirkeby, C.; Kristensen, B.; Kjaer, L.J.; Sorensen, J.H.; Bodker, R. Microclimatic temperatures increase the potential for vector-borne disease transmission in the Scandinavian climate. Sci. Rep. 2017, 7, 8175. [CrossRef] [PubMed]

277. Blosser, E.M.; Lord, C.C.; Stenn, T.; Acevedo, C.; Hassan, H.K.; Reeves, L.E.; Unnasch, T.R.; Burkett-Cadena, N.D. Environmental Drivers of Seasonal Patterns of Host Utilization by Culiseta melanura (Diptera: Culicidae) in Florida. J. Med. Entomol. 2017, 54, 1365-1374. [CrossRef]

(C) 2019 by the authors. Licensee MDPI, Basel, Switzerland. This article is an open access article distributed under the terms and conditions of the Creative Commons Attribution (CC BY) license (http://creativecommons.org/licenses/by/4.0/). 